
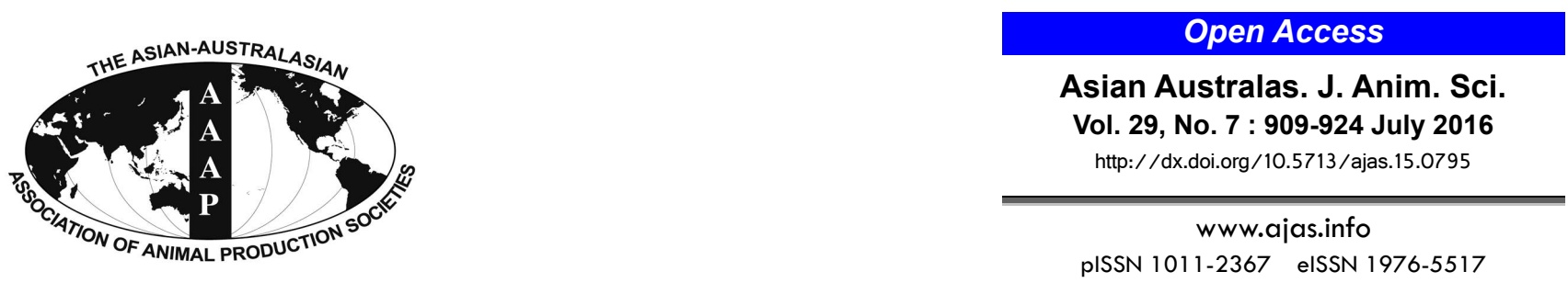

\title{
Gut Health of Pigs: Challenge Models and Response Criteria with a Critical Analysis of the Effectiveness of Selected Feed Additives - A Review
}

\author{
D. I. Adewole, I. H. Kim ${ }^{1}$, and C. M. Nyachoti* \\ Department of Animal Science, Winnipeg, MB R3T 2N2, Canada
}

\begin{abstract}
The gut is the largest organ that helps with the immune function. Gut health, especially in young pigs has a significant benefit to health and performance. In an attempt to maintain and enhance intestinal health in pigs and improve productivity in the absence of in-feed antibiotics, researchers have evaluated a wide range of feed additives. Some of these additives such as zinc oxide, copper sulphate, egg yolk antibodies, mannan-oligosaccharides and spray dried porcine plasma and their effectiveness are discussed in this review. One approach to evaluate the effectiveness of these additives in vivo is to use an appropriate disease challenge model. Over the years, researchers have used a number of challenge models which include the use of specific strains of enterotoxigenic Escherichia coli, bacteria lipopolysaccharide challenge, oral challenge with Salmonella enteric serotype Typhimurium, sanitation challenge, and Lawsonia intercellularis challenge. These challenge models together with the criteria used to evaluate the responses of the animals to them are also discussed in this review. (Key Words: Challenge Models, Feed Additives, Gut Health, Pigs, Response Criteria)
\end{abstract}

\section{INTRODUCTION}

Gut health is a term increasingly used in the medical literature and by the food industry. It covers multiple positive aspects of the gastrointestinal tract (GIT), such as the effective digestion and absorption of food, the absence of gastrointestinal illness, normal and stable intestinal microbiota, effective immune status and a state of wellbeing (Bischoff, 2011). The GIT of a pig is a complex environment. Particularly in newborns and around the time of weaning, the pigs' gut rapidly changes in size, has high protein turnover rates, undergoes rapid changes in microbiota, and quickly alters its digestive and immune functions (Pluske et al., 1997).

The correct functional development of the GIT is of special importance during the weaning phase of reared piglets (Domeneghini et al., 2006). The mucosal epithelium of the small intestine is reputed anatomically and

\footnotetext{
* Corresponding Author: C. M. Nyachoti. Tel: +1-204-474-7323, Fax: +1-204-474-7628, E-mail: martin_nyachoti@umanitoba.ca

1 Department of Animal Resources and Science, Dankook University, Cheonan 330-714, Korea.

Submitted Sept. 23, 2015; Revised Oct. 20, 2015; Accepted Nov. 11, 2015
}

functionally immature in neonatal pigs, a feature that appears to be exacerbated at weaning, when a colonization of the gut occurs by new microorganisms entering the alimentary canal with solid feed. This frequently exposes piglets to diarrhoeic syndromes and other intestinal disturbances (Domeneghini et al., 2006). In the lifespan of the pig, the neonatal and weaning phases represent critical periods for both the correct development of the gut and the growth of the young animal (Pluske et al., 1997; Lay et al., 2001). The correct and timely functional development of the GIT, in which it should be able to sustain growing digestive, absorptive and immune functions, is of particular importance for these adaptable processes correctly occurring (Domeneghini et al., 2006). The GIT serves a key functional role in the growth of the young piglet, even though it represents a relatively small fraction of its body weight (BW), in that it is approximately $2 \%$ of BW at birth and increases nearly threefold, to more than $6 \%$, two weeks after weaning (Shields et al., 1983; Mitchell et al., 2001).

To improve productivity of pigs, researchers have evaluated a wide range of feed additives (such as immunoglobulin, omega 3 fatty acids, yeast derived B glucans, organic and inorganic acids, high levels of zinc 
oxide, essential oils, herbs and spices, some types of prebiotics, bacteriophages and anti-microbial peptides, probiotics, glutamine, threonine, cysteine, and nucleotides) as substitute products for antibiotics. The role of these additives and their potential use in managing gut health and function in newly weaned pigs has been reviewed extensively elsewhere (de Lange et al., 2010; Heo et al., 2013; Thacker, 2013; Zeng et al., 2015).

An approach to evaluate the efficacy of various additives as replacements for antibiotics in vivo is to use an appropriate disease challenge model. Over the years, researchers have used a number of in vivo challenge models some of which were discussed in this review.

\section{DISEASE CHALLENGE MODELS}

\section{Post-weaning diarrhea using specific pathogenic strains of enterotoxigenic Escherichia coli}

Enterotoxigenic Escherichia coli (ETEC) is the main causative agent of diarrhea in weaned pigs. It attaches to and effaces the intestinal mucosa, thus leading to malabsorption of large molecules as a result of a compromised barrier function. The ETEC diarrhea is the most common enteric disease in piglets, accounting for $50 \%$ of the piglets that die annually worldwide (Gyles, 1994). Investigations have indicated that colonization of the small intestine of the piglet by ETEC adhering to the epithelium accounts for most gastrointestinal disorders (Yolken et al., 1988) (Table 1). The fimbrial K88, K99, and 987P antigens of porcine ETEC that are associated with intestinal colonization have been extensively investigated with respect to their genetic background, protein chemistry, and immunological properties (Fusco et al., 1978).

Enterotoxigenic Escherichia coli (E. coli) K88 is the pathogen most frequently isolated in piglets and associated with colibacillosis. Studies (Owusu-Asiedu et al., 2002; Owusu-Asiedu et al., 2003; Bhandari et al., 2008) have demonstrated the suitability of ETEC K88 challenge model in evaluating the role of feed additives in nursery pig diets. Oral challenge with ETEC has been used widely as model for post-weaning diarrhea (PWD) (Wellock et al., 2009) and has often been used in pig feeding trials to assess the ability of a diet to reduce the infection or its consequences (Bosi et al., 2004a, b). Dietary phytogenics could be used to replace antibiotic growth promoters (AGP) in the diets of weaning pigs for significantly improving the average daily gain (ADG) without any negative effects on growth performance under challenge with E.coli K88 compared with AGP and organic acids (Mohana Devi et al., 2015).

Response criteria: In this challenge model, a number of response criteria are usually used. The most common among them are growth performance, fecal consistency score, plasma urea nitrogen (PUN), fecal and tissue bacteria number, intestinal morphology (villus height $[\mathrm{VH}]$ and crypt depth $[\mathrm{CD}])$, serum concentrations of haptoglobin, tumor necrosis factor (TNF- $\alpha$ ), interleukin 6 (IL-6), and interferon-gamma (INF- $\gamma$ ), number of intestinal adherent bacteria, digesta $\mathrm{pH}$, rectal temperature (RT) and mortality. Some of these response criteria are discussed below.

Growth performance: Average daily feed intake (ADFI), $\mathrm{ADG}$, and feed conversion efficiency (G:F) have been used as response criteria during ETEC challenge. Marquardt et al. (1999) orally challenged pigs with $5 \mathrm{~mL}$ of $E$. coli $\mathrm{K}^{+} 8^{+}$at a dose of $10^{10}$ colony-forming unit $(\mathrm{cfu}) / \mathrm{mL}$ and reported that pigs lost weight within $48 \mathrm{~h}$ post-challenge. At $72 \mathrm{~h}$ after ETEC challenge, Marquardt et al. (1999) reported 68.5\% reduction in ADG. Using the same ETEC strain, OwusuAsiedu et al. (2003) reported no effect but a tendency of reduction in ADFI and ADG upon challenge. Bhandari et al. (2008) and Nyachoti et al. (2012) similarly reported that growth performance was not affected by ETEC challenge. However, reduction in growth performance was reported by a number of researchers (Trevisi et al., 2009; Song et al., 2011; Lee et al., 2012).

The reason why a reduction in growth performance was not achieved in all cases as expected is worthy of investigation. Factors to be considered are: The species of pigs used in the different experiments, age of pigs at the time of challenge, variation in the volume and dosage of inoculants used, buffer type and method of delivery of the inoculants into the oral cavity of pigs, health status of pigs prior to ETEC challenge, duration of the experiment and duration of acclimatization prior to challenge. For example, Trevisi et al. (2009) used $1.5 \mathrm{~mL}$ of inoculant as opposed to the $5 \mathrm{~mL}$ used by Marquardt et al. (1999) and the $6 \mathrm{~mL}$ used by Nyachoti et al. (2012). Also, Bhandari et al. (2008) and Marquardt et al. (1999) used a concentration of $6.3 \times 10^{10}$ $\mathrm{cfu} / \mathrm{mL}$ and $5 \times 10^{10} \mathrm{cfu} / \mathrm{mL}$ of ETEC inoculants, respectively, as opposed to the $1 \times 10^{10}$ used by other researchers (Owusu-Asiedu et al., 2003).

Fecal consistency score: This has been used by many researchers to quantify the severity of diarrhea. The scoring method commonly used is the 0 to 3 scoring system; where $0=$ normal feces, $1=$ soft feces, $2=$ mild diarrhea, and $3=$ severe diarrhea. Yokoyama et al. (1992) reported that all piglets developed mild to severe diarrhea within $12 \mathrm{~h}$ of ETEC infection. Similarly, Owusu-Asiedu et al. (2003) reported that $3 \mathrm{~d}$ after oral ETEC challenge, piglets had severe diarrhea with scour score of 2.8 that lasted for more than 7 d. Nyachoti et al. (2012) reported that fecal consistency score reduced from 1.07 at $6 \mathrm{~h}$ post-infection to 0.94 at $120 \mathrm{~h}$ post-challenge. Song et al. (2011) reported that $E$. coli challenge did increase diarrhea scores and frequency. Lee et al. (2012) reported that ETEC challenge increased scouring until $336 \mathrm{~h}$ post-infection. Kahindi (2014) after inoculating pigs with 6 and $15 \mathrm{~mL}$ of 
Table 1. Challenge models and responses in weaned pigs

\begin{tabular}{|c|c|c|c|}
\hline Dose of inoculants & Observations & $\begin{array}{l}\text { Age or BW } \\
\text { of pigs }\end{array}$ & References \\
\hline \multicolumn{4}{|l|}{ PWD using specific pathogenic strains of ETEC } \\
\hline \multicolumn{4}{|l|}{ Growth performance responses } \\
\hline $5 \mathrm{~mL}$ of $E$. coli $\mathrm{K} 88^{+} \mathrm{MB}$ at $10^{10} \mathrm{cfu} / \mathrm{mL}$ & $68.5 \%$ reduction in $\mathrm{ADG}$ & $3 \mathrm{~d}$ & $\begin{array}{l}\text { Marquardt et al., } \\
1999\end{array}$ \\
\hline $6 \mathrm{~mL}$ ETEC K $88^{+}$at $10^{10} \mathrm{cfu} / \mathrm{mL}$ & Tendency of reduction in overall ADG and ADFI & $10 \mathrm{~d}$ & $\begin{array}{l}\text { Owusu-Asiedu et al., } \\
2003\end{array}$ \\
\hline $6 \mathrm{~mL}$ of $6.3 \times 10^{9} \mathrm{cfu} / \mathrm{mL}$ of $E$. coli inoculants & Growth performance was not affected by challenge & $17 \mathrm{~d}$ & Bhandari et al., 2008 \\
\hline $\begin{array}{l}1.5 \mathrm{~mL} \text { suspension containing } 10^{10} \mathrm{cfu} \\
\text { of E. coli } \mathrm{K} 88 \mathrm{ac} 0149 / \mathrm{mL}\end{array}$ & Reduced growth performance after ETEC challenge & 20 to $21 \mathrm{~d}$ & $\begin{array}{l}\text { Lee et al., 2012; } \\
\text { Trevisi et al., } 2009\end{array}$ \\
\hline $6 \mathrm{~mL}$ ETEC solution at $2 \times 10^{9} \mathrm{cfu} / \mathrm{mL}$ & No difference in growth performance after ETEC challenge & $17 \mathrm{~d}$ & Nyachoti et al., 2012 \\
\hline \multicolumn{4}{|l|}{ Severity of diarrhea } \\
\hline $5 \mathrm{~mL} \mathrm{~K} 88^{+} \mathrm{ETEC}$ at $10^{12} \mathrm{cfu} / \mathrm{mL}$ & Mild to severe diarrhea within $12 \mathrm{~h}$ of infection & $1 \mathrm{~d}$ & $\begin{array}{l}\text { Yokoyama et al., } \\
1992\end{array}$ \\
\hline $5 \mathrm{~mL}$ of $E$. coli $\mathrm{K} 88^{+} \mathrm{MB}$ at $10^{10} \mathrm{cfu} / \mathrm{mL}$ & Severe to moderate diarrhea within $10 \mathrm{~h}$ of infection & $3 \mathrm{~d}$ & $\begin{array}{l}\text { Marquardt et al., } \\
1999\end{array}$ \\
\hline $5 \mathrm{~mL}$ of E. coli $\mathrm{K} 88^{+} \mathrm{MB}$ at $10^{10} \mathrm{cfu} / \mathrm{mL}$ & Severe diarrhea within $12 \mathrm{~h}$ of infection & $21 \mathrm{~d}$ & $\begin{array}{l}\text { Marquardt et al., } \\
1999\end{array}$ \\
\hline $6 \mathrm{~mL}$ ETEC solution at $2 \times 10^{9} \mathrm{cfu} / \mathrm{mL}$ & Diarrhea episode was not achieved & $17 \mathrm{~d}$ & Nyachoti et al., 2012 \\
\hline $6 \mathrm{~mL}$ ETEC $\mathrm{K} 88^{+}$at $10^{10} \mathrm{cfu} / \mathrm{mL}$ & Severe diarrhea $3 \mathrm{~d}$ after challenge that lasted for more than $7 \mathrm{~d}$ & $10 \mathrm{~d}$ & $\begin{array}{l}\text { Owusu-Asiedu et al., } \\
2003\end{array}$ \\
\hline $6 \mathrm{~mL}$ of $6.3 \times 10^{9} \mathrm{cfu} / \mathrm{mL}$ of $E$. coli inoculants & Scoring was higher at $24 \mathrm{~h}$ post-infection & $17 \mathrm{~d}$ & Bhandari et al., 2008 \\
\hline $1 \times 10^{9} \mathrm{cfu} / \mathrm{mL}$ of ETEC $\mathrm{K} 88 \mathrm{ac}$ & Increased scouring until $336 \mathrm{~h}$ post-infection & $20 \mathrm{~d}$ & Lee et al., 2012 \\
\hline \multicolumn{4}{|l|}{ Bacteria lipopolysaccharide challenge } \\
\hline \multicolumn{4}{|l|}{ Growth performance responses } \\
\hline 0.5 to $50 \mu \mathrm{g} / \mathrm{kg}$ LPS from E. coli $\mathrm{K} 235$ & Reduced feed intake & 32 to $46 \mathrm{~kg}$ & $\begin{array}{l}\text { Johnson and Von } \\
\text { Borel, } 1994\end{array}$ \\
\hline $200 \mu \mathrm{g} / \mathrm{kg}$ BW E. coli LPS & Reduced ADG and ADFI & $28 \mathrm{~d}$ & Liu et al., 2003 \\
\hline $200 \mu \mathrm{g} / \mathrm{kg}$ LPS & Reduction in ADG and tendency of reduction in ADFI & $14 \mathrm{~d}$ & Jiang et al., 2009 \\
\hline \multicolumn{4}{|l|}{ Plasma urea nitrogen (PUN) } \\
\hline $5 \mu \mathrm{g} / \mathrm{kg}$ E. coli $\mathrm{K} 235 \mathrm{LPS}$ & Elevated PUN & $11.55 \mathrm{~kg}$ & Webel et al., 1997 \\
\hline $0.5 \mu \mathrm{g} / \mathrm{kg}$ E. coli $\mathrm{K} 235 \mathrm{LPS}$ & No effect on PUN & $11.55 \mathrm{~kg}$ & Webel et al., 1997 \\
\hline \multicolumn{4}{|l|}{ Intestinal morphology } \\
\hline $200 \mu \mathrm{g} / \mathrm{kg}$ LPS & $\begin{array}{l}\text { Increased crypt depth of the duodenum and decreased the villus } \\
\text { height:crypt depth of ileum }\end{array}$ & $14 \mathrm{~d}$ & Jiang et al., 2009 \\
\hline \multicolumn{4}{|c|}{ Plasma IGF-1 concentration and concentration of TNF- $\alpha$} \\
\hline $50 \mu \mathrm{g} / \mathrm{kg} \mathrm{BW}$ LPS & $\begin{array}{l}\text { Increased plasma IGF-1 concentration and also increased TNF- } \alpha \\
\text { concentration }\end{array}$ & $56 \mathrm{~d}$ & Wang et al., 2011 \\
\hline \multicolumn{4}{|c|}{ Oral challenge with Salmonella enteric serotype Typhimurium } \\
\hline \multicolumn{4}{|l|}{ Growth performance responses } \\
\hline $3 \times 10^{9} \mathrm{cfu} / \mathrm{ml}$ of $S$. typhimurium & Reduction in feed intake and daily BW gain & $5 \mathrm{wk}$ & Balaji et al., 2000 \\
\hline $3.3 \times 10^{9} \mathrm{cfu} / \mathrm{mL}$ & Reduction in ADG, ADFI, and G:F & $24 \mathrm{~d}$ & Turner et al., 2002 \\
\hline \multicolumn{4}{|l|}{ Rectal temperature (RT) } \\
\hline $3.3 \times 10^{9} \mathrm{cfu} / \mathrm{mL}$ & $\begin{array}{l}\text { Higher RT on d 1-4 after challenge but returned to levels similar } \\
\text { to control on d } 5\end{array}$ & $24 \mathrm{~d}$ & Turner et al., 2002 \\
\hline $3 \times 10^{9} \mathrm{cfu} / \mathrm{mL}$ of $S$. typhimurium & $\begin{array}{l}\text { Elevated at } 12 \text { post-infection, peaked at } 42 \mathrm{~h} \text { post-infection and } \\
\text { remained elevated throughout the study }\end{array}$ & $5 \mathrm{wk}$ & Balaji et al., 2000 \\
\hline $1 \times 10^{9} \mathrm{cfu} / \mathrm{mL}$ of $S$. typhimurium & $\begin{array}{l}\text { Increased RT in Salmonella challenged pigs on d } 7 \text { after } \\
\text { challenge and declined on d } 14 \text { after challenge }\end{array}$ & $38.7 \mathrm{~kg}$ & Gebru et al., 2010 \\
\hline
\end{tabular}

BW, body weight; PWD, post-weaning diarrhea; ETEC, enterotoxigenic Escherichia coli; ADG, average daily gain; ADFI, average daily feed intake; LPS, lipopolysaccharide; IGF-1, insulin-like growth factor 1 ; TNF- $\alpha$, tumor necrosis factor- $\alpha$; G:F, feed conversion efficiency.

ciprofloxacin-resistant ETEC $\mathrm{K}^{8} 8^{+}\left(5 \times 10^{9} \mathrm{cfu} / \mathrm{mL}\right)$, concentrations in diets. PUN has been used as an indicator reported that pigs had normal feces pre-challenge, but fecal for amino acids breakdown as a result of less than optimal score slightly changed in the post-challenge period due to systemic amino acids supply for protein synthesis (Coma et increased incidence of diarrhea.

Plasma urea nitrogen: Nitrogen metabolism in pigs has al., 1996) and of muscle protein breakdown to release amino acids for synthesizing acute phase proteins in the been evaluated as a rapid response indicator of amino acid liver as a response to immune system activation 
(Wannemacher, 1977). Owusu-Asiedu et al. (2003) reported that PUN levels were higher upon ETEC challenge. The results of Kiarie et al. (2009) also indicated that pigs had elevated PUN at $24 \mathrm{~h}$ post-challenge. However, Bhandari et al. (2008) reported contrarily that PUN reduced from 6.23 to $5.53 \mathrm{mmol} / \mathrm{L}$ after $7 \mathrm{~d}$ of infection with ETEC. The higher PUN concentration in the challenged pigs as reported by Owusu-Asiedu et al. (2003) and Kiarie et al. (2009) could either be an indication of increased muscle protein breakdown to release amino acids for synthesizing acute phase proteins in the liver and/or to serve as an energy source because of lower feed intake in this group of pigs.

Intestinal morphology: The morphology of the intestinal mucosa is an important indicator that reflects the development of the digestive tract and the response of intestine to certain feed substances (Boguslawka-Tryk et al., 2012). It is commonly believed that an increased VH and a decreased crypts depth is positively correlated to the digestive and absorptive functions in the GIT of animals, accounting for an enlarged absorptive area and a reduced tissue turnover rate (Xu et al., 2003; Munyaka et al., 2012; Shang, 2014). Opapeju et al. (2009) reported no difference in $\mathrm{VH}$ and $\mathrm{CD}$ after $7 \mathrm{~d}$ of ETEC challenge. No difference in VH:CD was observed by Trevisi et al. (2009) after $7 \mathrm{~d}$ of ETEC challenge as well. However, shorter villi were observed in the duodenum by Owusu-Asiedu et al. (2003) after ETEC challenge. CDs were similar and were not influenced by ETEC challenge (Owusu-Asiedu et al., 2003).

Serum concentrations of haptoglobin, tumor necrosis factor $\alpha$, interleukin- 6 , and interferon-gamma: These proinflammatory cytokines play a critical role in normal host resistance to infection, serving as immunomodulators and as mediators of inflammatory responses. They are primarily produced by activated macrophages through numerous signals, such as mitogenic or antigenic stimulation, lipopolysaccharide (LPS), calcium ionophores, cytokines and viruses. Serum IL-6, IL-1 $\beta$, and IL-10 increased with time post-challenge (Kiarie et al., 2009). Similarly, Nyachoti et al. (2012) reported that TNF- $\alpha$ increased from 111.4 to $162.1 \mathrm{~g} / \mathrm{mL}$ upon ETEC challenge. Also, Lee et al. (2012) reported increased concentration of serum haptoglobin, TNF- $\alpha$, IL-6, and INF- $\gamma$ compared with control. Recently, Kahindi (2014) reported an increase in TNF- $\alpha$ concentration after $6 \mathrm{~h}$ inoculation with 6 and $15 \mathrm{~mL}$ of ciprofloxacin-resistant ETEC K88 $\left(5 \times 10^{9} \mathrm{cfu} / \mathrm{mL}\right)$.

\section{Lipopolysaccharide challenge}

Lipopolysaccharide is a molecule present on the outer surface of all gram-negative bacteria which is widely used as an immune stimulant (Chapman et al., 2005). It is a potent inflammatory mediator and has been used to model bacterial infection experimentally in farm animals (Yang et al., 2008). Many aspects of inflammation caused by infection with gram-negative bacteria can be mimicked by administration of LPS (Shini et al., 2008 as cited by Munyaka, 2012). Lipopolysaccharide challenge is a welldocumented model for inducing symptoms of acute bacterial infection and immunological stress in laboratory animals. The biological effects mediated by LPS are attributed to a cascade of cytokine synthesis and release by stimulated macrophages (Dinarello, 1984) and a subsequent increase in prostaglandin synthesis (Hashimoto et al., 1988). It is well documented that an immunological challenge can result in a series of physiological changes including increased body temperature, depressed feed intake, changes in plasma acute phase protein concentration, activation of the immune system, activation of the hypothalamicpituitary-adrenal axis, and inhibition of the somatotropic axis (Johnson, 1997). Consequently the immunological challenge results in the poor growth of livestock and may increase economic loss for animal producers (Liu et al., 2003). Zhang et al. (2008) reported a growth improving effect of $\beta$-glucan at 50 and $75 \mathrm{mg} / \mathrm{kg}$ in the diet in broilers.

One emerging view is that these changes are attributed to the release of pro-inflammatory cytokines (Johnson, 1997). The effects of LPS are due to its ability to stimulate macrophages to synthesize and secrete pro-inflammatory cytokines (Johnson and von Borrel, 1994). Whether LPS is indicative of on-farm conditions is a subject of much debate; however, it is obvious that its administration activates several immune defences, which allows one to better understand the physiology of infection and inflammation due to an immunological challenge (Liu et al., 2003). According to Mohsen and Kim (2014), supplementation of stevia in growing pigs improves blood immunity and alleviates the inflammatory responses in LPS challenge.

Response criteria: In pigs, LPS which is the primary toxic component of endotoxin induces symptoms of acute bacterial infection, including anorexia, hypersomnia, and fever. The most common response criteria include growth performance, PUN, concentrations of TNF- $\alpha$, IL-1, and IL6, plasma cortisol, insulin-like growth factor 1 (IGF-1), and growth hormone $(\mathrm{GH})$ concentrations, and Intestinal morphology which are discussed below.

Growth performance: Johnson and Von Borel (1994) reported that growing pigs injected with 0.5 or $50 \mu \mathrm{g} / \mathrm{kg}$ LPS from E. coli serotype K-235 had lower feed intake compared with control after $2 \mathrm{~h}$. At 4 to $8 \mathrm{~h}$, only the pigs receiving the highest dose $(50 \mu \mathrm{g} / \mathrm{kg})$ of LPS experienced a reduction in feed intake and feed motivated behaviour whereas pigs receiving $0.5 \mu \mathrm{g} / \mathrm{kg}$ demonstrated a compensatory increase in feed intake suggesting that although LPS is a potent inhibitor of feed-motivated behaviour, its effects are short-lived. Following the same model, Liu et al. (2003) administered E. coli LPS serotype 
055:B5 as an inflammatory agent. During the first challenge period (d 14 to 21), LPS challenge reduced ADG and ADFI compared with the saline-treated pigs. During the second challenge period (d 21 to 28), pigs challenged with LPS had lower ADG than saline-treated pigs but ADFI was not affected. This indicated that the response of pigs to the first LPS was stronger than the response to the second injection. In another study by Jiang et al. (2009), $200 \mu \mathrm{g} / \mathrm{kg}$ LPS was injected intramuscularly on $\mathrm{d} 7$ and 14 after blood sampling. During the challenge period (d 7 to 21 ), inflammatory challenge with LPS reduced ADG and tended to reduce ADFI compared with that of phosphate-buffered saline treated piglets. Inclusion of $0.1 \% \beta$-glucan and $0.1 \%$ kefir, either individually or combined, would improve growth performance and benefit meat quality in broiler chickens (Cho et al., 2013)

Plasma urea nitrogen: PUN is an indicator of protein catabolism in feed-deprived animals. Increased protein degradation is a typical response in early feed-deprived conditions because amino acids are needed as gluconeogenic substrates in the liver (Webel et al., 1997). Webel et al. (1997) reported that PUN levels were elevated two- and threefold at 8 and $12 \mathrm{~h}$ respectively, in pigs injected with $5 \mu \mathrm{g} / \mathrm{kg}$ LPS $E$. coli serotype K-235. Whereas administration of $0.5 \mu \mathrm{g} / \mathrm{kg}$ LPS had no effect on PUN levels. There was a trend for increased PUN levels at $24 \mathrm{~h}$ after injection that could be explained by proteolysis typical of an extended period without feed.

Concentrations of $T N F-\alpha, \quad I L-1, \quad$ and $I L-6$ : Intraperitoneal injection of LPS to pigs increased plasma levels TNF- $\alpha$ and IL-6 (Webel et al., 1997). It also increased plasma level of IL-1 and skeletal muscle protein degradation in rodents (Jepson et al., 1986; Fong et al., 1989; Goodman, 1991). Serum TNF- $\alpha$ reached peak concentrations after $1 \mathrm{~h}$ LPS administration and returned to near baseline levels $3.5 \mathrm{~h}$ after challenge (Frank et al., 2003). Also, LPS challenge ( $50 \mu / \mathrm{kg} \mathrm{BW})$ increased TNF- $\alpha$ concentration (Wang et al., 2011).

Plasma cortisol, insulin-like growth factor 1, and growth hormone concentrations: Administration of LPS increased the activity of the hypothalamic-pituitary-adrenal axis, as evidenced by increased plasma cortisol levels (Webel et al., 1997). Lipopolysaccharide challenge reduced plasma IGF-1 but no LPS challenge effect was observed for plasma GH when $200 \mu \mathrm{g} / \mathrm{kg}$ BW was used (Liu et al., 2003). Lipopolysaccharide challenge increased IGF-1 concentration (Wang et al., 2011).

Intestinal morphology: Jiang et al. (2009) reported that piglets injected with LPS $(200 \mu \mathrm{g} / \mathrm{kg} \mathrm{BW})$ had shorter duodenum $\mathrm{VH}$ and decreased ileum $\mathrm{VH}: \mathrm{CD}$ compared with control and which implies that LPS challenge might indirectly have affected small intestinal morphology by inducing the reduction of ADFI.
Although LPS models have been important in the elucidation of the integrated pathophysiology of infection and inflammation, this approach has limitations because it does not completely mimic the physiological changes that would occur during a bona fide infectious disease (Balaji et al., 2000). The LPS model has the following limitations: i) LPS induces a short duration response rather than a chronic immunological stress (Balaji et al., 2000) ii) pigs develop a tolerance to the multiple, subsequent LPS challenges, which was observe in the study of Kegley et al. (2001) and Liu et al. (2003), and iii) LPS and live E. coli challenge induce different immunological profiles in the weaned pigs (Zanneli et al., 2000).

\section{Oral challenge with Salmonella enteric serotype Typhimurium}

Salmonellosis is one of the most common foodborne bacteria diseases in the world (Forshell and Wierup, 2006). It is an important disease in humans and is usually associated with contaminated food, including pork products (Ojha and Kostrzynka, 2007). In addition to human health implications, Salmonella typhimurium (ST) is a pathogen of considerable importance in worldwide animal production (Forshell and Wierup, 2006). Salmonellosis in swine is one of the top 10 most common diseases in weaning and grower/finisher pigs (Haley et al., 2012).

Response criteria: Swine salmonellosis can be symptomatic or asymptomatic, and, consequently, difficult to diagnose (Rostagno and Callaway, 2012). Pigs colonized with salmonella usually exhibit varied severity and duration of fecal shedding and costly decrease in growth performance (Knetter et al., 2015). The porcine immune response to ST is also characterised largely by the local production of pro-inflammatory mediators that result in the pyrexial and neutrophil influx considered hallmarks of ST infection (Hobbie et al., 1997 as cited in Knetter et al., 2015). The response criteria that are commonly measured are discussed in detail below.

Growth performance: Balaji et al. (2000) observed that feed intake was reduced maximally in salmonella challenged pigs at $48 \mathrm{~h}$ and remained reduced through $120 \mathrm{~h}$ after challenge with $3 \times 10^{9} \mathrm{cfu} / \mathrm{mL}$ of $\mathrm{S}$. typhimurium. Daily BW gain also was reduced during the 2 wk following infection. Turner et al. (2002) observed a reduction in ADG, ADFI, and G:F when weaned pigs were exposed to an oral challenge with $3.3 \times 10^{9} \mathrm{cfu} / \mathrm{mL}$ ST during wk 3 of the study. It must be noted that Turner et al. (2002) used an experimental design that did not provide an optimal test for the effects of enteric disease challenge. That is, diseasechallenged pigs and uninfected pigs were housed in separate rooms which made the effects of enteric disease challenge to be confounded with room.

Rectal temperature and Salmonella typhimurium 
shedding: Turner et al. (2002) reported that RT of control pigs remained constant during $7 \mathrm{~d}$ after challenge, whereas ST challenge resulted in a distinct and expected febrile response. Rectal temperatures of ST challenged pigs were higher on $\mathrm{d} 1$ to 4 after challenge but returned to levels similar to controls by d 5 after challenge (Turner et al., 2002). Rectal temperatures were elevated in ST challenged pigs relative to control pigs by $12 \mathrm{~h}$, peaked at $42 \mathrm{~h}$, and remained elevated throughout the remainder of the study (Balaji et al., 2000). Rectal temperature was increased in pigs challenged with $1 \times 10^{9} \mathrm{cfu} / \mathrm{mL}$ ST (Gebru et al., 2010). Bacteria shedding scores were higher in ST challenged pigs on $\mathrm{d} 7$ after challenge and declined on $\mathrm{d} 14$ post-challenge (Gebru et al., 2010). Knetter et al. (2015) reported that pigs ( 7 to $8 \mathrm{wk}$ of age) challenged with $1 \times 10^{9}$ cfu of S. enterica serovar Typhimurium were quantitatively positive for salmonella shedding in fecal swabs while control pigs remained negative.

Plasma and serum insulin-like growth factor 1 concentration: Balaji et al. (2000) reported a marked suppression of plasma IGF-1 occurred in ST challenged IGF-1 concentrations declined from pre-infection concentrations on $\mathrm{d} 2$, increased on $\mathrm{d} 4$, and declined again until d 13 (Gebru et al., 2010). Circulating IGF-1 is sensitive to acute changes in feed intake and can, therefore, provide useful ancillary data as an indicator of the severity of the disease process (Burkey et al., 2004). Consistent reduction in circulating IGF-1 after ST challenge were reported in enteric disease challenged pigs (White et al., 1991). Serum IGF-1 concentration is affected in part by decreased feed intake. Individual animal differences in other factors such as $\mathrm{GH}$, insulin, and thyroid hormones (Morovat and Dauncey, 1998) might contribute to changes in IGF-1 concentrations.

Acute phase proteins concentration: Salmonella typhimurium challenge produced a rise in serum haptoglobin and $\alpha_{1}$-acid glycoprotein (AGP) on d 7 after challenge but levels were comparable to controls by d 14 after challenge (Turner et al., 2002). The fact that AGP and haptoglobin levels in ST challenged pigs were higher on $\mathrm{d} 7$ suggests that these acute phase proteins are appropriate indicators of the acute enteric disease experienced by infected pigs during the $7 \mathrm{~d}$ following ST challenge. Serum haptoglobin increased on $\mathrm{d} 6$ and declined to pre-challenge concentrations on d 13 (Gebru et al., 2010).

\section{SANITATION CHALLENGE MODEL}

Le Floc'h et al. (2006) suggested that modifications of the environment and the sanitary status could be a way of stimulating an immune response of piglets reared in conventional facilities because it had been observed that unclean housing conditions expose pigs to different kinds of stressors that can lead to stimulation of the immune system, thus affecting animal performance. A number of researchers (Lee et al., 2005; Le Floc'h et al., 2006; 2009; Kahindi, 2014) have used the sanitation challenge model in studies with pigs. Lee et al. (2005) created a dirty environment by not cleaning the piglets' shed prior to stocking and throughout the experimental period and by recycling effluent continuously beneath the floor slats in an effort to maintain increased noxious gas levels. On the other hand, the clean shed was disinfected thoroughly prior to stocking and maintained in a clean state by daily hosing of pens and aisles, flushing effluent channels with clean water and twice daily fogging the air space with a virucidal agent. Le Floc'h et al. $(2006,2009)$ achieved a low sanitary status by using a non-sanitized room which was neither disinfected nor cleaned after previous occupation by pigs and without antibiotic supplementation in diets. High sanitary status was achieved by using a cleaned and disinfected room with antibiotic supplementation in the diets. Kahindi (2014) achieved unclean sanitary conditions by using a room previously occupied by pigs without the room being cleaned and by adding manure slurry from a sow herd ( 5 $\mathrm{kg} / \mathrm{pen}$ ) to the expanded metal floor of $1.2 \times 1.8 \mathrm{~m}$ before piglets were introduced into the room to further enhance unclean conditions. The spread of manure was repeated one week after the introduction of the piglets and the room remained uncleaned throughout the experimental period. On the other hand, clean sanitary conditions were achieved by cleaning and disinfecting the room prior to the start of the experiment and by cleaning the room once in a week throughout the experimental period.

The challenge with the use of this model is the difficult in standardizing unsanitary conditions and determine with certainty the causative agent for any immunological response observed. This makes it difficult to reproduce the model over time and among laboratories.

\section{Response criteria}

Rearing pigs under unclean sanitary conditions has been used as a model to provoke a low-grade inflammatory response. Pigs subjected to these conditions had reduced growth performance and an activated immune system that would interfere with growth because of competition between protein deposition in structural tissues and immune function (Jayaraman et al., 2015). The response criteria commonly measured in this model are discussed in detail below.

\section{Growth performance}

Lee et al. (2005) reported that pigs reared in a clean environment consumed more feed and grew faster than those housed in the dirty environment. There was no significant difference in feed conversion efficiency between 
the two treatments. Le Floc'h et al. (2006) reported that after $45 \mathrm{~d}$ of experimentation, pigs kept in bad sanitary conditions displayed depressed growth rate and feed conversion ratio compared to pigs reared in good sanitary conditions. Average final BW of pigs reared in bad sanitary conditions was reduced by $1.3 \mathrm{~kg}$. ADFI was also reduced by poor sanitary conditions. In a $21 \mathrm{~d}$ experiment, Kahindi (2014) reported that the ADG and G:F were lower for pigs raised under unclean conditions compared with their clean counterparts during $\mathrm{d} 0$ to 14 but the effect on ADG disappeared during d 15 to 21 which suggested that the ability of piglets to deal with an immunological stress improved with age and that they were able to adapt to their environment with time. However, the overall ADG was still lower for pigs raised under unclean conditions compared with those raised under clean conditions indicating that piglets were unable to fully overcome the effects of being subjected to unclean housing conditions (Kahindi, 2014; Kahindi et al., 2014). In a meta-analysis by Pastorelli et al. (2012), it was concluded that sanitary challenges negatively affect feed intake and growth, leading to a negative impact on animal well-being and economic losses. It has been suggested that the growth reduction after a sanitary challenge is not only due to the reduction in ADFI but also due to an increase in requirements related to digestive and metabolic processes (Sandberg et al., 2007).

\section{Plasma parameters}

Le Floc'h et al. (2006) reported that Plasma haptoglobin concentrations were numerically higher in high sanitary status than in low sanitary status piglets but the difference was significant only 13 days after the beginning of the experiment. Pig kept in poor sanitary conditions had greater concentrations of haptoglobin than pigs housed in good sanitary conditions (Le Floc'h et al., 2009). Plasma cortisol concentrations were significantly higher in pigs housed in dirty environment than in pigs housed in clean environment (Lee et al., 2005). Plasma IGF-1 concentrations were lower in pigs housed in dirty environment compared to those housed in clean environment (Lee et al., 2005).

\section{OTHER CHALLENGE MODELS}

Other disease challenge models that have been used in swine nutrition includes: Lawsonia intracellularis challenge (Whitney et al., 2006) and porcine reproductive and respiratory syndrome virus challenge (Boddicker et al., 2012). In cattle, disease challenge models such as bovine rhinotracheitis virus challenge (Schutz et al., 2012) and bovine viral diarrhea virus and Mannhimia haemolytica (Rose-Dye et al., 2010) have been used. Lawsonia intracellularis is the causative agent of ileitis, or porcine proliferative enteropathy (PPE) which is an enteric disease in swine. The intracellular bacteria infect immature epithelia cells located in the crypts of the villi of the intestine. Cellular proliferation and thickening of the infected intestine occur and may result in necrosis, ulceration, or hemorrhaging of the epithelial surface, or all of these (Whitney et al., 2006). Lawsonia intracellularis is present in approximately $75 \%$ of all US swine herds (Bronsvoort et al., 2001). Whitney et al. (2006) challenged pigs orally with $1.5 \times 109 \mathrm{cfu} / \mathrm{mL}$ after a 4 -wk pre-challenge feeding period. The researchers discovered that compared with unchallenged pigs, challenging pigs with $L$. intracellularis reduced growth rate, feed intake, and efficiency of gain and increased gauntness and diarrhea.

\section{CRITICAL ANALYSIS OF THE EFFECTIVENESS OF FEED ADDITIVES IN PIG NUTRITION}

A major challenge facing the swine industry is to identify means for controlling diarrhea in young pigs that are not only cost effective, but also suitable for sustainable pork production (Owusu-Asiedu et al., 2003). Feed additives are primarily alternative substances to the use of antibacterial agents and chemotherapeutics during weaning on the rearing farm, as they can adequately stimulate the local defensive responses, and favourably influence resident gastrointestinal microflora, but also able to improve nutrient digestion and absorption (Domeneghini et al., 2006). The feed additives to be considered in this review are zinc salts, copper salts, egg yolk antibodies, spray dried porcine plasma and mannan-oligosaccharides (MOS).

\section{Zinc oxide}

In the late 1980's, reports began filtering into the United States from Europe that the use of pharmacological levels of zinc $(\mathrm{Zn})$ as zinc oxide $(\mathrm{ZnO})$, was an effective means of treating diarrhea in young pigs (Holm, 1988; Poulsen, 1989) (Table 2). A few experiments were subsequently conducted in the United States to test this theory. One of the series of studies involving high $\mathrm{Zn}$ diets was conducted by Hahn and Baker (1993) at the University of Illinois. Like most planned experiments, the researchers were unable to test whether $\mathrm{ZnO}$ was effective in preventing diarrhea scours because they did not encounter any diarrhea in any of their pigs, including the controls. However, they did find that in each of the 3 experiments, $\mathrm{ZnO}$ stimulated growth rate of the pigs. Averaged across the 3 trials, $\mathrm{ZnO}$ supplementation at 3,000 and 5,000 ppm increased daily weight gains by $17 \%$ and $20 \%$, respectively and daily feed intakes by $14 \%$ and $12 \%$, respectively (Hahn and Baker, 1993). Also, $\mathrm{ZnSO}_{4}$ supplementation at 3,000 and 5,000 ppm increased daily weight gains by $16.6 \%$ and $1.5 \%$, respectively, and daily feed intakes by $9.7 \%$ and $5.42 \%$, respectively. At concentrations greater than 1,000 ppm, 
Table 2. Effects of feeding $\mathrm{Zn}$ as $\mathrm{ZnO}$ on growth performance of piglets

\begin{tabular}{|c|c|c|c|c|}
\hline \multirow{2}{*}{ Level of supplemental $\mathrm{Zn}(\mathrm{ppm})$} & \multicolumn{2}{|c|}{$\%$ Increase relative to control } & \multirow{2}{*}{$\begin{array}{l}\text { Age of pig } \\
\text { (d) }\end{array}$} & \multirow{2}{*}{ References } \\
\hline & ADG & ADFI & & \\
\hline 3,000 & 13.5 & 13.1 & $28-35$ & Hahn and Baker, 1993 \\
\hline 3,000 & 15.7 & 11.3 & $12-15$ & Smith et al., 1997 \\
\hline 3,110 & -2 & -1.4 & $17-19$ & Smith et al., 1997 \\
\hline 5,000 & 20.09 & 12.34 & 35 & Hahn and Baker, 1993 \\
\hline 500 & 5.9 & 1 & $15-21$ & Hill et al., 2001 \\
\hline 1,000 & 8.9 & 1.7 & $15-21$ & Hill et al., 2001 \\
\hline 2,000 & 19.8 & 24 & $15-21$ & Hill et al., 2001 \\
\hline 3,000 & 13 & 9 & $15-21$ & Hill et al., 2001 \\
\hline 3,000 & 21.5 & 26.2 & 28 & Li et al., 2006 \\
\hline
\end{tabular}

plasma $\mathrm{Zn}$ increased linearly for all 3 sources of $\mathrm{Zn}(\mathrm{ZnO}$, $\mathrm{ZnSO}_{4}, \mathrm{Zn}$-Lys complex). Plasma $\mathrm{Zn}$ of pigs fed $\mathrm{ZnO}$ was only $55 \%$ of the value obtained from pigs fed $\mathrm{ZnSO}_{4}$ whereas plasma $\mathrm{Zn}$ of pigs fed Zn-Met was $120 \%$ of the plasma $\mathrm{Zn}$ value obtained from pigs fed $\mathrm{ZnSO}_{4}$ (Hahn and Baker, 1993). This observation shows that pigs utilize $\mathrm{Zn}$ from $\mathrm{ZnO}$ far less efficiently than $\mathrm{Zn}$ from $\mathrm{ZnSO}_{4}$.

Evidence from Wedekind and Lewis (1993) also demonstrated that bone $\mathrm{Zn}$ accumulation in pigs fed $\mathrm{ZnO}$ is only $67 \%$ to $70 \%$ as great as that in pigs fed $\mathrm{ZnSO}_{4}$. Thus, plasma $\mathrm{Zn}$ concentration in pigs fed high levels of added $\mathrm{Zn}$ (between 1,000 and 5,000 $\mathrm{mg}$ of $\mathrm{Zn} / \mathrm{kg}$ ) may represent a useful and non-invasive means of assessing $\mathrm{Zn}$ bioavailability of various inorganic $\mathrm{Zn}$ sources (Hahn and Baker, 1993).

Smith et al. (1997) reported increase in ADG and ADFI when pigs were fed 3,000 ppm $\mathrm{Zn}$ from $\mathrm{ZnO}$. Specifically, compared to the basal diet, supplementing pigs' diet with $3,000 \mathrm{ppm}$ of $\mathrm{Zn}$ from $\mathrm{ZnO}$ led to $27 \%$ increase in ADG and 17.7\% increase in ADFI (Smith et al., 1997). Both traditionally weaned and early weaned pigs fed 3,000 ppm of $\mathrm{Zn}$ had higher $\mathrm{ADG}$ and plasma and liver $\mathrm{Zn}$ concentrations for the entire 28-d period compared with pigs fed adequate $\mathrm{Zn}$ (Carlson et al., 1999).

Other researchers (Carlson et al., 1995; Poulsen, 1995; Smith et al., 1997) have reported a range of $10 \%$ to $26 \%$ increase in growth performance when nursery pigs are fed pharmacological (2,500 to 4,000 ppm) concentrations of $\mathrm{Zn}$. Poulsen (1995) reported that a supplement of 2,500 ppm Zn as $\mathrm{ZnO}$ fed to weanling pigs for 2 weeks reduced the incidence and severity of non-specific PWD by up to $50 \%$. Researchers from 10 Universities in the United States cooperated in a study to investigate the impact of pharmacological dietary $\mathrm{Zn}$ on performance of weanling pigs with diverse health status and housing conditions. Improved daily growth (15\%) and feed intake (11\%) were found with 3,000 ppm $\mathrm{Zn}$ in diet (Hill et al., 1996).

Another cooperative study involving 9 University research stations in the United States evaluated the effects of different dietary $\mathrm{ZnO}$ concentrations (0, 500, 1,000,
$1,500,2,000$, and 3,000 $\mathrm{mg} \mathrm{Zn} / \mathrm{kg}$ ) on the performance of post-weaning pigs and reported that weight gains, feed intakes, and gain:feed ratios increased by approximately $10 \%, 5 \%$, and $5 \%$, respectively, when pigs were fed 2,000 $\mathrm{mg} \mathrm{Zn/kg} \mathrm{diet} \mathrm{compared} \mathrm{with} \mathrm{those} \mathrm{that} \mathrm{were} \mathrm{fed} \mathrm{basal} \mathrm{diets}$ (Hill et al., 2001). The results clearly demonstrated a growth response to added $\mathrm{ZnO}$ that reached a plateau at dietary concentrations of 1,500 to $2,000 \mathrm{mg} \mathrm{Zn} / \mathrm{kg}$.

Also, Li et al. (2006) reported that adding 3,000 mg $\mathrm{Zn} / \mathrm{kg}$ in the form of $\mathrm{ZnO}$ to the diet of weanling pigs increased daily BW gain by $21.5 \%$ and daily feed intake by $26.2 \%$. A new and important finding from the study of Li et al. (2006) was that dietary $\mathrm{Zn}$ supplementation increased $\mathrm{VH}$ of the piglet by $13.5 \%$. This provides a useful model with which to test the hypothesis that dietary supplementation with high levels of $\mathrm{Zn}$ improves intestinal structure and function by increasing intestinal expression of the IGF-1 and $I G F-1 R$ genes (Li et al., 2006).

There is much speculation about the mechanism responsible for the effect of high levels of $\mathrm{ZnO}$ in promoting piglet performance. The $\mathrm{Zn}$ ion is considered to be a major causative factor on the basis of the observation that a higher bioavailability of $\mathrm{Zn}$ was associated with a better growth-promoting effect (Hahn and Baker, 1993). However, $\mathrm{ZnO}$, whose bioavailability is much lower than that of $\mathrm{ZnSO}_{4}$ or zinc-methionine complex (Zn-Met) (Wedekind et al., 1994) had a stronger growth-promoting effect than $\mathrm{ZnSO}_{4}$ or Zn-Met (Hahn and Baker, 1993; Wedekind et al., 1994).

Furthermore, Mavromichalis et al. (2000) found that both high (93\%) and low (39\%) bioavailability of $\mathrm{ZnO}$ had the same performance-enhancing effect in piglets. These findings indicate that the bioavailability of a high level of $\mathrm{Zn}$ in the diet is not a major factor affecting growth performance in piglets. It was noted in recent times that the use of high doses of inorganic $\mathrm{Zn}$ has raised concern due to elevated $\mathrm{Zn}$ in feces when fed for more than $10 \mathrm{~d}$ (Rincker et al., 2005). Therefore, Castillo et al. (2008) evaluated the efficacy of a source of organic $\mathrm{Zn}$ (Bioplex $\mathrm{Zn}$ ) to enhance growth performance, gastrointestinal health, and immune 
response in weaned pigs. The trial of Castillo et al. (2008) was based on the hypothesis that if the mode of action of $\mathrm{Zn}$ is based on a systematic effect, an organic form of $\mathrm{Zn}$ with greater bioavailability would allow reduced concentration in feed and subsequent release in the environment while maintaining benefits to the animals. It was found that the use of Bioplex $\mathrm{Zn}$ improved G:F in the starter period, improved fecal scores for the first $21 \mathrm{~d}$, decreased enterobacteria counts in the jejunum, but had no effect on the serum concentration of the immunoglobulins and ileal IgA in the jejunum (Castillo et al., 2008). Supplementing $\mathrm{ZnO}$ increased serum $\mathrm{Zn}$, which reduced serum $\mathrm{P}$ and $\mathrm{Ca}$, indicating $\mathrm{Ca}-\mathrm{Zn}-\mathrm{P}$ precipitation. In addition, phytase increased serum $\mathrm{Ca}$, but only in the absence of $\mathrm{Zn}$, further indicating a complex interaction between $\mathrm{Zn}, \mathrm{Ca}$, and $\mathrm{P}$ in the blood (Walk et al., 2012).

\section{Copper sulphate}

Copper is a unique mineral element in that it acts as a growth stimulant in swine when fed at high dietary levels (Cromwell et al., 1989). The sulphate salt of $\mathrm{Cu}$ is the most common source used in feeds for growth promotion (Table 3 ). It is routinely supplemented to weanling pig diets at concentrations above the nutritional requirement of the animal. Cromwell et al. (1989) evaluated the efficacy of various levels $(0,30,125,250,375$, and $500 \mathrm{ppm})$ of dietary $\mathrm{Cu}$ as a growth promoter for weanling pigs. Dietary inclusion of $250 \mathrm{ppm}$ level of CuSO 4 improved growth rate by $24 \%$ to $39 \%$ and improved efficiency of feed utilization by $11 \%$ to $21 \%$. Feed intake also was increased by $8 \%$ to $17 \%$ in pigs fed this dietary level. The magnitude of the improvement in growth performance was diminished when $\mathrm{CuSO}_{4}$ was increased to $375 \mathrm{ppm}$ and was completely lost when diet was increased to $500 \mathrm{ppm} \mathrm{Cu}$.

Dove (1995) in a nutrient balance study with weanling pigs, evaluated the effect of $\mathrm{Cu}$ supplementation on the ability of nursery pigs utilize nutrients from diets containing 0 or $5 \%$ supplemental animal fat. He found that pigs fed diets with $5 \%$ added fat and $15 \mathrm{ppm} \mathrm{Cu}$ had increased growth rate and feed efficiency compared with pigs fed $0 \%$ fat and $15 \mathrm{ppm}$ of $\mathrm{Cu}$ diet or pigs fed the $0 \%$ fat and 250 $\mathrm{ppm}$ of $\mathrm{Cu}$ diet. ADFI was increased by the addition of 250 ppm of $\mathrm{Cu}$ to the diet. Pigs fed $250 \mathrm{ppm}$ of $\mathrm{Cu}$ consumed $15.7 \%$ more feed than did pigs fed the $15 \mathrm{ppm}$ of $\mathrm{Cu}$ diet. This is a direct reflection of the increased gain and feed efficiency observed in these pigs because pigs were fed based on BW. The addition of $\mathrm{Cu}$ increased the apparent digestibility of fat at both levels of fat indicating that $\mathrm{Cu}$ played a role in the digestion of animal fat.

Studies with finishing pigs indicate that $\mathrm{Cu}$ increases the level of unsaturated fatty acids in backfat (Amer and Elliot, 1973). Ho and Elliot (1974) suggested that $\mathrm{Cu}$ enhanced the specific activities of the fatty acyl desaturase systems, thus altering the composition of the depot fat. Armstrong et al. (2004) determined the efficacy of copper source (copper citrate and $\mathrm{CuSO}_{4}$ ) and dietary concentration on growth performance and fecal $\mathrm{Cu}$ excretion in weanling pigs, as well as the effect on odor characteristics of swine waste. They observed that feeding $250 \mathrm{ppm} \mathrm{Cu}$ as $\mathrm{CuSO}_{4}$ improved growth rate and feed efficiency over the $45 \mathrm{~d}$ nursery period.

Of further interest in the study of Armstrong et al. (2004) was that lower dietary $\mathrm{Cu}$ concentrations (125 ppm), regardless of source, were as effective at stimulating gain as $250 \mathrm{ppm} \mathrm{Cu}$ from $\mathrm{CuSO}_{4}$. In agreement with this data, 100 to $125 \mathrm{ppm} \mathrm{Cu}$ has been shown to improve growth performance at rates similar to $250 \mathrm{ppm} \mathrm{Cu}$ (Roof and Mahan, 1982; Coffey et al., 1994). Previous research has indicated that pigs normally excrete $70 \%$ to $95 \%$ of the $\mathrm{Cu}$ consumed in diets (Kornegay and Harper, 1997). This poor retention of $\mathrm{Cu}$ by the pig when pharmacological concentrations of $\mathrm{Cu}$ are fed presents an environmental concern, because excess $\mathrm{Cu}$ in swine feces results in $\mathrm{Cu}$ accumulation in the soil (Armstrong et al., 2004). There was no effect of dietary $\mathrm{Cu}$, regardless of $\mathrm{Cu}$ source on the odor characteristics of swine waste even though previous

Table 3. Effect of feeding $\mathrm{CuSO}_{4}$ on growth performance, plasma $\mathrm{Cu}$, fecal $\mathrm{Cu}$, and liver $\mathrm{Cu}$ of pigs

\begin{tabular}{|c|c|c|c|c|c|c|c|}
\hline \multirow{2}{*}{$\begin{array}{l}\text { Level of } \\
\text { supplemental } \mathrm{Cu} \\
(\mathrm{ppm})\end{array}$} & \multicolumn{5}{|c|}{$\%$ Increase relative to basal/control diet } & \multirow[b]{2}{*}{$\begin{array}{l}\text { Age of pig } \\
\text { (d) }\end{array}$} & \multirow[b]{2}{*}{ References } \\
\hline & ADG & ADFI & $\begin{array}{c}\text { Plasma Cu } \\
(\mathrm{mg} / \mathrm{L})\end{array}$ & $\begin{array}{c}\text { Fecal Cu } \\
(\mathrm{mg} / \mathrm{kg})\end{array}$ & $\begin{array}{c}\text { Liver } \mathrm{Cu} \\
\text { (ppm of } \mathrm{DM})\end{array}$ & & \\
\hline 125 & 14.4 & 9.5 & - & - & - & $16-18$ & Armstrong et al., 2004 \\
\hline 250 & 11.3 & 6.8 & -6.2 & 1,121 & - & $16-18$ & Armstrong et al., 2004 \\
\hline 62 & 1.7 & 0.02 & -6.2 & 243.6 & - & $16-18$ & Armstrong et al., 2004 \\
\hline 250 & 7.8 & 11.3 & - & - & - & 26 & Dove, 1995 \\
\hline 250 & 32 & 11.8 & - & - & $1,005.9$ & 28 & Cromwell et al., 1989 \\
\hline 125 & 25.8 & 12 & - & - & 20.3 & 28 & Cromwell et al., 1989 \\
\hline 500 & 3.1 & 6.9 & - & - & 1,322 & 28 & Cromwell et al., 1989 \\
\hline 375 & 15.4 & 8 & - & - & 4,043 & 28 & Cromwell et al., 1989 \\
\hline 550 & 0 & -13 & - & - & 7,105 & 28 & Cromwell et al., 1989 \\
\hline
\end{tabular}

ADG, average daily gain; ADFI, average daily feed intake; DM, dry matter. 
research has demonstrated that $\mathrm{Cu}$ supplementation to nursery diets improved the odor characteristics of swine waste (Armstrong et al., 2000).

\section{Egg yolk antibodies}

Oral administration of antibodies derived from serum and colostrum and even with monoclonal antibodies has been very successful. Of particular veterinary interest is the use of chicken egg yolk antibodies for the treatment of porcine colibacillosis (Yokoyama et al., 1992) (Table 4). Vaccination of laying hens provides a cheaper and good alternative antibody source; the eggs are collected after a high level of antibodies is reached in the egg yolk (Yokoyama et al., 1992). Yolken et al. (1988) suggested that egg preparations might serve as source of antiviral antibodies for humans. The first clinical use of spray dried chicken egg yolk antibodies against ETEC infection in piglets was first described by Yokoyama et al. (1992). The different therapeutic regimens with various titers $(0,156$, 625 , and 2,500) of anti-K88, -K99, and -987P antibodies reduced considerably the severity of diarrhea in piglets receiving high-titer antibodies (Yokoyama et al., 1992). On the basis of their findings, the antibody titer of 2,500 was considered the most efficacious in protecting piglets from the proliferation of ETEC strains in the intestinal tract and its harmful consequences.

Jin et al. (1998) demonstrated in an in vitro study that purified antibody from the yolk of chicken immunized against E. coli (K88) was able to block the binding of ETEC K88 to the mucosal receptor and prolonged incubation of egg-yolk antibodies and that ETEC did not further reduce the degree of adhesion of ETEC to mucus and that egg-yolk antibodies were unable to displace ETEC once the bacteria were attached to the mucus of the small intestine.

Marquardt et al. (1999) demonstrated that egg-yolk antibodies protected both neonatal and 21-d-old weaned piglets from diarrhea induced by a challenge with $E$. coli K88+ MB. Owusu-Asiedu et al. (2003) demonstrated that egg-yolk antibody has important therapeutic and prophylactic value in the diets of early-weaned pigs by
Table 5. The effects of spray dried animal plasma (SDAP) and autoclaved SDAP (auSDAP) on growth performance and serum insulin of 21-d-old piglets ${ }^{1}$

\begin{tabular}{lccccc}
\hline Item & Control & SDAP & auSDAP & $\begin{array}{c}\text { Pooled } \\
\text { SEM }\end{array}$ & p-value \\
\hline Initial BW (kg) & 2.17 & 2.16 & 2.17 & 0.09 & 0.991 \\
Final BW (kg) & 5.73 & 6.58 & 6.36 & 0.24 & 0.056 \\
ADG (g) & $209.43^{\mathrm{a}}$ & $260.33^{\mathrm{b}}$ & $246.98^{\mathrm{ab}}$ & 10.72 & 0.012 \\
ADFI (g) & $240.79^{\mathrm{a}}$ & $293.63^{\mathrm{b}}$ & $284.1^{\mathrm{b}}$ & 8.79 & 0.002 \\
G:F & 0.87 & 0.89 & 0.87 & 0.02 & 0.700 \\
Insulin (ng/mL) & $2.40^{\mathrm{ab}}$ & $2.42^{\mathrm{b}}$ & $2.32^{\mathrm{a}}$ & 0.03 & 0.047 \\
\hline
\end{tabular}

SEM, standard error of the mean; BW, body weight; ADG, average daily gain; ADFI, average daily feed intake; G:F, feed conversion efficiency.

${ }^{1}$ SDAP, spray-dried animal protein and auSDAP, autoclaved SDAP. $n=6$.

a,b Means in a row without a common letter differ $(\mathrm{p}<0.05)$.

Adapted from Gao et al. (2011).

controlling and preventing enterotoxigenic E. coli infection, thereby improving pig performance.

Also, Owusu-Asiedu et al. (2003) assessed the effectiveness of egg yolk antibodies $(0.3 \%$ and $0.2 \%$ egg yolk powder containing specific anti-K88 and anti-F18 antibodies, respectively) in controlling ETEC relative to conventional additives in early weaned pigs fed pea protein isolate based diets. Piglets fed egg yolk antibodies recovered $3 \mathrm{~d}$ after ETEC challenge indicating that the presence of the specific anti-ETEC antibody binds the $E$. coli, thereby preventing colonization and proliferation, resulting in subsequent removal of the $E$. coli.

\section{Spray-dried porcine plasma}

Spray-dried porcine plasma (SDPP) has been used widely in the diet of early weaned pigs since it has been shown to greatly improve weight gains $(10 \%$ to $50 \%)$ as a result of increased feed intake (Coffey and Cromwell 1995; Jiang et al., 2000). It has been shown that the feeding of SDPP reduces the incidence and severity of diarrhea in young pigs (Van der Peet-Schwering and Binnendijk, 1995) (Table 5). It was reported by Frank et al. (2003) that pigs fed diet containing 7\% spray dried plasma had a $52 \mathrm{~g} / \mathrm{kg}$ reduction in G:F compared to the pigs fed diet with no spray dried plasma.

Table 4. Effect of feeding egg-yolk antibody on pigs' growth performance, plasma urea nitrogen, intestinal morphology and protection against diarrhea

\begin{tabular}{|c|c|c|c|c|c|c|}
\hline \multirow{2}{*}{$\begin{array}{l}\text { Amount or } \\
\% \text { of } \\
\text { egg-yolk } \\
\text { antibody } \\
\text { in diet }\end{array}$} & \multicolumn{4}{|c|}{ Observations relative to control } & \multirow[b]{2}{*}{$\begin{array}{l}\text { Age of pig } \\
\text { (d) }\end{array}$} & \multirow[b]{2}{*}{ References } \\
\hline & $\begin{array}{c}\text { No of pigs with } \\
\text { diarrhea after } 48 \mathrm{~h} \\
(\%)\end{array}$ & $\begin{array}{c}\text { Weight gain } \\
(\%)\end{array}$ & $\begin{array}{c}\text { PUN } \\
(\%)\end{array}$ & $\begin{array}{c}\text { Villous } \\
\text { height:crypt depth } \\
(\%)\end{array}$ & & \\
\hline $1.5 \mathrm{~g}$ & Decreased by 50 & Increased by 145.8 & - & - & 3 & Marquardt et al., 1999 \\
\hline $0.5 \mathrm{~g}$ & Decreased by 100 & Increased by 350 & - & - & 21 & Marquardt et al., 1999 \\
\hline $0.5 \%$ & - & Increased by 18.4 & Decreased by 9.4 & - & 10 & Owusu-Asiedu et al., 2002 \\
\hline $0.5 \%$ & Decreased by 51.9 & Increased by 50 & Decreased by 11.9 & Increased by 82.4 & 10 & Owusu-Asiedu et al., 2003 \\
\hline
\end{tabular}

PUN, plasma urea nitrogen. 
Bosi et al. (2004a) demonstrated that feeding piglets a diet containing spray-dried plasma improves growth and protects against ETEC K88 infection by maintaining mucosal integrity, enhancing specific antibody defense, and decreasing inflammatory cytokine expression in intestine. The data of Bosi et al. (2004b) also provided support that SDPP is a better source of protein than fish for weanling pigs. Results from Gao et al. (2011) demonstrated that spray dried animal plasma (SDAP) addition increased ADG and ADFI by $24.3 \%$ and $21 \%$, respectively, whereas G:F was not affected. These findings are consistent with the results which reported that mean SDAP-induced changes in ADG, ADFI, and G:F in the first $2 \mathrm{wk}$ for pigs weaned at a postnatal age greater than $4 \mathrm{~d}$ were $26.8,24.5$, and -3.2 , respectively (van Dijk et al., 2001).

Autoclaved SDAP was reported to improve ADG and ADFI by $15 \%$ and $18 \%$, respectively (Gao et al., 2011). The improvements of ADG and ADFI by autoclaved SDAP which were less than those by SDAP indicated that the heatsensitive immunoglobins only partially contributed to the benefits of SDAP. Owusu-Asiedu et al. (2002) reported that autoclaved SDAP decreased feed intake and ADG, which was inconsistent with the results of Gao et al. (2011). However, the results of Owusu-Asiedu et al. (2002) plus those of others and results from Gao et al. (2011) indicate that factors other than immunoglobins, including growth factors, cytokines, and other unknown compounds, in SDAP could have physiological impacts (Moreto and PerezBosque, 2009).

Peace et al. (2011) evaluated the effects of $2.5 \%$ and $5 \%$ dietary inclusion levels of SDPP on post-weaning intestinal barrier function, mucosal inflammation, and clinical indices of gut health in pigs. The researchers demonstrated that dietary inclusion of $2.5 \%$ and $5 \%$ SDPP reduced ileal and colonic paracellular permeability of ${ }^{14} \mathrm{C}$-inulin and reduced ileal ${ }^{3} \mathrm{H}$-mannitol compared with controls. The 5\% SDPP diet reduced colonic short-circuit current, an index of net electrogenic ion transport, and fecal scores. This demonstrated a beneficial role of SDPP inclusion in ameliorating intestinal barrier dysfunction, mucosal inflammation, and diarrhea observed during the post- weaning period in pigs (Peace et al., 2011)

\section{Mannan-oligosaccharides}

Prebiotics which were first identified and named by Gibson and Roberfroid (1995) are non-digestible food ingredients, which stimulate the growth or activity or both of bacteria in the digestive system. In swine nutrition, prebiotics, probiotics, and sybiotics seem to be functional components with beneficial effects on growth performance, gastrointestinal function and health. LeMieux et al. (2003) reported that MOS has been used as prebiotics in livestock feeds. Mannan-oligosaccharides consist of a mannan and a glucan component (Table 6). The structure of the mannan component resembles that of the carbohydrates on the gut wall. Mannan-oligosaccharides derived from yeast cell wall may offer an alternative to traditional ingredients (such as antibiotics, $\mathrm{Cu}$, and excess $\mathrm{Zn}$ ) resulting in equal or better growth performance of nursery pigs (Davis et al., 2002). Fructan supplementation improved growth performance and apparent total tract digestibility (ATTD) of dry matter (DM) and gross energy (GE), improved the fecal microbial balance, and inhibited the fecal E. coli. Furthermore, fructan may decrease fecal noxious gas emissions by finishing pigs (Zhao et al., 2103).

The MOS has the ability to influence the microbial population in the intestinal tracts (Davis et al., 2002). This modification is accomplished by the ability of MOS to attach to mannose binding proteins on the cell surface of some strains of bacteria, thereby preventing these bacteria from colonizing the intestinal tract by interfering with the binding of carbohydrate residues on epithelia cell surfaces (Spring et al., 2000). Dietary supplementation with $0.10 \%$ levan-type fructan can improve growth performance, digestibility, and fecal Lactobacillus counts, and has a beneficial effect on the immune response during an inflammatory challenge in growing pigs (Li and Kim, 2013).

The results of Davis et al. (2002) indicated that the addition of MOS to swine diets moderately improved weight gain and feed efficiency. However, the magnitude of response was not as great as that observed with pharmacological additions of $\mathrm{Cu}$. White et al. (2002) also

Table 6. Effects of mannan oligosaccharides (MOS) on growth performance, diarrhea score and serum IgG of weanling pigs

\begin{tabular}{|c|c|c|c|c|c|c|}
\hline \multirow{2}{*}{$\begin{array}{l}\% \text { of MOS } \\
\text { in diet }\end{array}$} & \multicolumn{4}{|c|}{ Observations relative to control } & \multirow{2}{*}{$\begin{array}{l}\text { Age of pig } \\
\text { (d) }\end{array}$} & \multirow{2}{*}{ References } \\
\hline & ADG $(\%)$ & ADFI $(\%)$ & Diarrhea $(\%)$ & Serum IgG $(\%)$ & & \\
\hline 0.1 & Increased by 23 & Increased by 29 & Decreased by 7 & - & 21 & Zhao et al., 2011 \\
\hline 0.2 & Increased by 2.3 & No effect & - & - & - & LeMieux et al., 2003 \\
\hline 0.3 & Increased by 1.4 & Decreased by 3.8 & - & - & - & LeMieux et al., 2003 \\
\hline 0.2 & Increased by 46.7 & Increased by 10.6 & - & - & 18 & Davis et al., 2002 \\
\hline 0.16 & Decreased by 8.8 & Decreased by 10.7 & - & Increased by 24 & 22 & White et al., 2002 \\
\hline 0.2 & Decreased by 6 & No effect & Decreased by 27 & - & 34 & Castillo et al., 2008 \\
\hline
\end{tabular}

IgG, Immunoglobulin G; ADG, average daily gain; ADFI, average daily feed intake. 
reported that yeast (containing 5.2\% MOS) reduced colonization of total coliforms in the duodenum, jejunum, cecum, and colon but did not have a consistent effect on colonization of $E$. coli K88. Pigs fed yeast tended to have higher serum IgG levels than controls (White et al., 2002). LeMieux et al. (2003) reported that addition of MOS to weanling pig diets increased growth performance during phase 2 of the nursery period but only when an antibiotic was included in the diet and when excess $\mathrm{Zn}$ was not included. Thus MOS may have the potential to replace excess $\mathrm{Zn}$ that is commonly added to nursery pig diets (LeMieux et al., 2003). Dietary supplementation of chitooligosccharide (COS) appeared to increase egg production and quality by increasing nutrient digestibility. Additionally, COS improved WBC and total protein concentration in laying hens (Meng et al., 2010).

Zhao et al. (2011) reported that pigs fed MOS diet for 28 days had greater ADG than pigs fed the negative control (basal without antibiotic). Pigs fed the positive control (basal+antibiotic) and MOS diets had increased ADFI compared with pigs fed the negative control diet. On d 14 of the experiment, the ATTD of DM and $\mathrm{n}$ in pigs fed the positive control and MOS diets were greater that the pigs fed the negative control diet (Zhao et al., 2011). Diarrhea score in pigs fed the MOS diet was reduced compared with pigs fed the negative control diet (Zhao et al., 2011). Addition of a dietary carbohydrate mixture ( $\alpha$-galactosidase and $\beta$-mannanase $0.05 \%$ ) could improve growth performance and nutrient digestibility of finishing pigs (Kim et al., 2013).

\section{CONCLUSION}

Various disease challenge models that have been used in animal nutrition include PWD using specific pathogenic strains of ETEC, bacteria LPS challenge, oral challenge with Salmonella enteric serotype Typhimurium, sanitation challenge and other challenge models such as Lawsonia intracellularis challenge. For oral ETEC challenge, varying volume $(1.5$ to $6 \mathrm{~mL})$ and varying concentrations $\left(10^{9}, 6.3 \times\right.$ $10^{9}, 10^{10}$ and $10^{12} \mathrm{cfu} / \mathrm{mL}$ ) of ETEC reduced growth performance and caused mild to severe diarrhea. For LPS challenge, a concentration of 5 to $200 \mu / \mathrm{kg}$ BW reduced growth performance, elevated PUN, altered intestinal morphology and increased plasma IGF-1 and TNF- $\alpha$ concentrations. For salmonella challenge, varying concentrations $\left(10^{9}, 3 \times 10^{9}\right.$, and $\left.3 \times 10^{9} \mathrm{cfu} / \mathrm{mL}\right)$ of ST caused reduction in growth performance and elevated RT. The sanitation model of immune challenge has proven to be effective when growth performance and PUN were used as response criteria, although this model does present significant challenges in terms of repeatability.

Feed additives such as $\mathrm{ZnO}, \mathrm{CuSO}_{4}$, spray-dried porcine plasma, egg-yolk antibodies, and MOS have been used by various researchers to improve growth and also to prevent diseases. The effectiveness of these additives depends majorly on the amount added to the diet. Above 1,000 ppm of $\mathrm{ZnO}$ and $100 \mathrm{ppm}$ of $\mathrm{CuSO}_{4}$, growth performance is enhanced while improvement in growth performance is lost above $3,000 \mathrm{ppm}$ of $\mathrm{ZnO}$ and $250 \mathrm{ppm}$ of $\mathrm{CuSO} 4$. Addition of $0.1 \%$ to $1.5 \%, 10 \%$, and $0.1 \%$ to $0.2 \%$ of egg-yolk antibodies, SDPP, and MOS, respectively, were effective in enhancing growth performance and preventing diarrhea in weanling pigs.

\section{CONFLICT OF INTEREST}

We certify that there is no conflict of interest with any financial organization regarding the material discussed in the manuscript.

\section{REFERENCES}

Amer, M. A. and J. E. Elliot. 1973. Influence of supplemental dietary copper and vitamin $\mathrm{E}$ on the oxidative stability of porcine depot fat. J. Anim. Sci. 37:87-90.

Armstrong, T. A., C. M. Williams, J. W. Spears, and S. S. Shiffman. 2000. High dietary copper improves odor characteristics of swine waste. J. Anim. Sci. 78:859-864.

Armstrong, T. A., D. R. Cook, M. M. Ward, C. M. Williams, and J. W. Spears. 2004. Effect of dietary copper source (cupric citrate and cupric sulfate) and concentration on growth performance and fecal copper excretion in weanling pigs. J. Anim. Sci. 82:1234-1240.

Balaji, R., K. J. Wright, C. M., Hill, S. S. Dritz, E. L. Knoppel, and J. E. Minton. 2000. Acute phase responses of pigs challenged orally with Salmonella typhimurium. J. Anim. Sci. 78:18851891.

Bhandari, S. K., B. Xu, C. M. Nyachoti, D. W. Giesting, and D. O. Krause. 2008. Evaluation of alternatives to antibiotics using an Escherichia coli K88+ model of piglet diarrhea: Effects on gut microbial ecology. J. Anim. Sci. 86:836-847.

Bischoff, S. C. 2011. 'Gut health': A new objective in medicine? BMC Med. 9:24-38.

Boddicker, N., E. H. Waide, R. R. Rowland, J. K. Lunney, D. J. Garrick, J. M. Reecy, and J. C. Dekkers. 2012. Evidence for a major QTL associated with host response to porcine reproductive and respiratory syndrome virus challenge. J. Anim. Sci. 90:1733-1746.

Bogusławska-Tryk, M., A. Piotrowska, and K. Burlikowska. 2012. Dietary fructans and their potential beneficial influence on health and performance parameters in broiler chickens. J. Cent. Eur. Agric. 13:272-291.

Bosi, P., L. Casini, A. Finamore, C. Cremokolini, G. Merialdi, P. Trevisi, F. Nobili, and E. Mengheri. 2004a. Spray-dried plasma improves growth performance and reduces inflammatory status of weaned pigs challenged with enterotoxigenic Escherichia coli K88. J. Anim. Sci. 82:1764-1772.

Bronsvoort, M., B. Norby, D. P. Bane, and I. A. Gardner. 2001. Management factors associated with seropositivity to 
Lawsonia intracellularis in U.S. swine herds. J. Swine Health Prod. 9:285-290.

Burkey, T. E., S. S. Dritz, J. C. Nietfeld, B. J. Johnson, and J. E. Minton. 2004. Effect of dietary mannanoligosaccharides and sodium chlorate on the growth performance, acute-phase response, and bacterial shedding of weaned pigs challenged with Salmonella enteric serotype Typhimurium. J. Anim. Sci. 82:397-404.

Carlson, M. S., G. M. Hill, J. E. Link, G. A. McCully, D. W. Rozeboom, and R. L. Weavers. 1995. Impact of zinc oxide and copper sulfate supplementation on the newly weaned pig. J. Anim. Sci. 73:72.

Carlson, M. S., G. M. Hill, and J. E. Link. 1999. Early- and traditionally weaned nursery pigs benefit from phase-feeding pharmacological concentrations of zinc oxide: Effect on metallothionein and mineral concentrations. J. Anim. Sci. 77:1199-1207.

Casini, L., P. Bosi, C. Gremokolini, P. Trevisi, M. Mazzoni, and P. Bonilauri. 2004b Oral challenge with E. coli $\mathrm{K} 88$ as a tool to assess growth and health performance in feeding trials of weaned pigs. Ital. J. Anim. Sci. Suppl 1. 2:358-360.

Castillo, M., S. M. Martin-Orue, J. A. Taylor-Pickard, J. F. Perez, and J. Gasa. 2008. Use of mannan-oligosaccharides and zinc chelate as growth promoters and diarrhea preventive in weaning pigs: Effects on microbiota and gut function. J. Anim. Sci. 86:94-101.

Chapman, M. E., W. Wang, G. F. Erf, and R. F. Widemand Jr. 2005. Pulmonary hypertensive responses of broilers to bacterial lipopolysaccharide (LPS); Evaluation of LPS source and dose and impact of pre-existing pulmonary hypertension and cellulose micro-particles selection. Poult. Sci. 84:432-441.

Cho, J. H., Z. F. Zhang, and I. H. Kim. 2013. Effects of single or combined dietary supplementation of $\beta$-glucan and kefir on growth performance, blood characteristics and meat quality in broilers. Br. Poult. Sci. 54:216-221.

Coffey, R. D. and G. L. Cromwell 1995. The impact of environment and antimicrobial agents on the growth response of early-weaned pigs to spray dried porcine plasma. J. Anim. Sci. 73:2532-2539.

Coffey, R. D., G. L. Cromwell, and H. J. Monegue. 1994. Efficacy of a copper-lysine complex as a growth promotant for weanling pigs. J. Anim. Sci. 72:2880-2886.

Coma, J., D. R. Zimmerman, and D. Carrion. 1996. Lysine requirement of the lactating sow determined by using plasma urea nitrogen as a rapid response criterion. J. Anim. Sci. 74: 1056-1062.

Cromwell, G. L., T. S. Stahly, and H. J. Monegue. 1989. Effects of source and level of copper on performance and liver copper stores in weanling pigs. J. Anim. Sci. 67:2996-3002.

Davis, M. E., C. V. Maxwell, D. C. Brown, B. Z. de Rodas, Z. B. Johnson, E. B. Kegley, D. H. Hellwig, and R. A. Dvorak. 2002. Effect of dietary mannanoligosaccharide and(or) pharmacological additions of supplemental copper on growth performance and immunocompetence of weanling and growing/finishing pigs. J. Anim. Sci. 80:2887-2894.

de Lange, C. F. M., J. Pluske, J. Gong, and C. M. Nyachoti. 2010. Strategic use of feed ingredients and feed additives to stimulate gut health and development in young pigs. Livest. Sci. 134:124-134.
Dinarello, C. A. 1984. Interleukin 1. Rev. Infect. Dis. 651.

Domeneghini, C., A. Di Giancamillo, S. Arrighi, and G. Bosi. 2006. Gut-trophic feed additives and their effects upon the gut structure and intestinal metabolism. State of the art in the pig, and perspectives towards humans. Histol. Histopathol. 21:273283.

Dove, C. R. 1995. The effect of copper level on nutrient utilization of weanling pigs. J. Anim. Sci. 73:166-171.

Dove, C. R. and K. D. Haydon. 1991. The effect of copper addition to diets with various iron levels on the performance and hematology of weanling swine. J. Anim. Sci. 69:20132019.

Fong, Y., L. L. Moldawer, M. Marano, H. Wei, A. Barber, K. Manogue, K. J. Tracey, G. Kuo, D. A. Fischman, A. Cerami, and S. F. Lowry. 1989. Cachectin/TNF or IL-1a induces cachexia with redistribution of body proteins. Am. J. Physiol. 256:R659-R665.

Forshell, L. P. and M. Wierup. 2006. Salmonella contamination: A significant challenge to the global marketing of animal food products. Rev. Off. Int. Epizoot. 25:541-554.

Frank, J. W., J. A. Carroll, G. L. Allee, and M. E. Zannelli. 2003. The effects of thermal environment and spray-dried plasma on the acute-phase response of pigs challenged with lipopolysaccharide. J. Anim. Sci. 81:1166-1176.

Fusco, P., A. To, S. To, and C. Brinton, Jr. 1978. The purification and characterization of four types of $E$. coli pili and the specificity of $E$. coli pili for immunity, colonization and adhesion. In: XIIIth US-Japan Conference on Cholera (Ed. C. Miller). Atlanta, GA, USA. pp. 60-70.

Gao, Y. Y., Z. Y. Jiang, Y. C. Lin, C. T. Zheng, G. L. Zhou, and F. Chen. 2011. Effects of spray-dried porcine plasma on serous and intestinal redox status and cytokines of neonatal piglets. J. Anim. Sci. 89:150-157.

Gebru, E., J. S. Lee, J. C. Son, S. Y. Yang, S. A. Shin, B. Kim, M. K. Kim, and S. C. Park. 2010. Effect of probiotic-, bacteriophage-, or organic acid-supplemented feeds or fermented soybean meal on the growth performance, acutephase response, and bacterial shedding of grower pigs challenged with Salmonella enteric serotype Typhimurium. J. Anim. Sci. 88:3880-3886.

Gheisar, M. M. and I. H. Kim. 2014. Effect of Dietary Stevia on immune response of growing pigs challenged with Escherichia coli lipopolysaccharide. Int. J. Agric. Innov. Res. 2:1174-1177.

Gibson, G. R. and M. B. Roberfroid. 1995. Dietary modulation of the human colonic microbiota: Introducing the concept of prebiotics. J. Nutr. 125:1401-1412.

Goodman, M. N. 1991. Tumor necrosis factor induces skeletal muscle protein breakdown in rats. Synergism with interleukin1. Am. J. Physiol. 260:E727-E730.

Gyles, C. L. 1994. Escherichia coli verotoxin and other cytotoxins. In: Escherichia coli in Domestic Animals and Humans., (Ed. C. L. Gyles). CAB International, Wallingford, UK. pp. 151-170.

Hahn, J. D. and D. H. Baker. 1993. Growth and plasma zinc responses of young pigs fed pharmacologic levels of zinc. J. Anim. Sci. 71:3020-3024.

Haley, C. A., D. A. Dargatz, E. J. Bush, M. M. Erdman, and P. J. Fedorka-Cray. 2012. Salmonella prevalence and antimicrobial susceptibility from the National Animal Health Monitoring System Swine 2000 and 2006 studies. J. Food Prot. 75:428- 
436.

Hashimoto, M., T. Bando, M. Iriki, and K. Hashimoto. 1988. Effect of indomethacin on febrile response to recombinant human interleukin 1-a in rabbits. Am. J. Physiol. 255:R527R533.

Heo J. M., F. O. Opapeju, J. R. Pluske, J. C. Kim, D. J. Hampson, and C. M. Nyachoti. 2013. Gastrointestinal health and function in weaned pigs: A review of feeding strategies to control postweaning diarrhoea without using in-feed antimicrobials. J. Anim. Physiol. Anim. Nutr. 97:207-237.

Hill, G. M., D. C. Mahan, S. D. Carter, G. L. Cromwell, R. C. Ewan, R. L. Harrold, A. J. Lewis, P. S. Miller, G. C. Shurson, and T. L. Veum. 2001. Effect of pharmacological concentrations of zinc oxide with or without inclusion of an antibacterial agent on nursery pig performance. J. Anim. Sci. 79:934-941.

Hill, G. M., G. L. Cromwell, T. D. Crenshaw, R. C. Ewan, D. A. Knabe, A. J. Lewis, D. C. Mahan, G. C. Shurson, L. L. Southern, and T. L. Veum. 1996. Impact of pharmacological intakes of zinc and (or) copper on performance of weanling pigs. J. Anim. Sci. 74:181.

Ho, S. K. and J. I. Elliot. 1974. Fatty acid composition of porcine depot fat as related to the effect of supplemental dietary copper on the specific activities of fatty acyl desaturase systems. Can. J. Anim. Sci. 54:23-28.

Hobbie, S., L. M. Chen, R. J. Davis, and J. E. Galan. 1997. Involvement of mitogen-activated protein kinase pathways in the nuclear responses and cytokine production induced by Salmonella typhimurium in cultured intestinal epithelia cells. J. Immunol. 159:5550-5559.

Holm, A. 1988. Escherichia coli induced weaning diarrhea in pigs. Dietary supplementation of zinc oxide as an antibacterial method? Dan. Veterinaertidsskr.71:1118-1126.

Jayaraman, B., J. Htoo, and C. M. Nyachoti. 2015. Effects of dietary threonine: lysine ratios and sanitary conditions on performance, plasma urea nitrogen, plasma-free threonine and lysine of weaned pigs. Anim. Nutr. 1:283-288.

Jepson, M. M., J. M. Pell, P. C. Bates, and D. J. Millward. 1986. The effects of endotoxaemia on protein metabolism in skeletal muscle and liver of fed and fasted rats. Biochem. J. 235:329336.

Jiang, R., X. Chang, B. Stoll, M. Z. Fan, J. Arthington, E. Weaver, J. Campbell, and D. G. Burrin. 2000. Dietary plasma protein reduces small intestinal growth and lamina propria cell density in early weaned pigs. J. Nutr. 130:21-26.

Jiang, Z. Y., L. H. Sun, Y. C. Lin, X. Y. Ma, C. T. Zheng, G. L. Zhou, F. Chen, and S. T. Zou. 2009. Effects of dietary glycylglutamine on growth performance, small intestinal integrity, and immune responses of weaning piglets challenged with lipopolysaccharide. J. Anim. Sci. 87:4050-4056.

Jin, L. Z., S. K. Baidoo, R. R. Marquardt, and A. A. Frohlich. 1998. In vitro inhibition of adhesion of enterotoxigenic Escherichia coli K88 to piglet intestinal mucus by egg-yolk antibodies. FEMS Immunol. Med. Microbiol. 21:313-321.

Johnson, R. W. 1997. Inhibition of growth by pro-inflammatory cytokines: an integrated view. J. Anim. Sci. 75:1244-1255.

Johnson, R. W. and E. von Borell. 1994. Lipopolysaccharideinduced sickness behaviour in pigs is inhibited by pretreatment with indomethacin. J. Anim. Sci. 72:309-314.
Kahindi, R. 2014. Assessment of Standardized Ileal Digestible Lysine and Sulphur Amino Acids to Lysine Ratio for Weaned Piglets Fed Antibiotic-Free Diets. Ph.D. Thesis, University of Manitoba, Winnipeg, MB, Canada.

Kahindi, R. K., J. K. Htoo, and C. M. Nyachoti. 2014. Short communication: Effect of dietary lysine content and sanitation conditions on performance of weaned pigs fed antibiotic-free diets. Can. J. Anim. Sci. 94:115-118.

Kegley, E. B., J. W. Spears, and S. K. Auman. 2001. Dietary phosphorus and an inflammatory challenge affect performance and immune function of weanling pigs. J. Anim. Sci. 79:413419.

Knetter, S. M., S. M. Bearson, T. H. Huang, D. Kurkiewicz, M. Schroyen, D. Nettleton, D. Berman, V. Cohen, J. K. Lunney, A. E. Ramer-Tait, M. J. Wannemuehler, and C. K. Tuggle. 2015. Salmonella enterica serovar Typhimurium-infected pigs with different shedding levels exhibit distinct clinical, peripheral cytokine and transcriptomic immune response phenotypes. Innate Immun. 21:227-241.

Kiarie, E., B. A. Slominski, D. O Krause, and C. M. Nyachoti. 2009. Acute phase response of piglets fed diets containing nonstarch polysaccharide hydrolysis products and egg yolk antibodies following an oral challenge with Escherichia coli (K88). Can. J. Anim. Sci. 89:353-360.

Kim, K. H., J. H. Cho, and I. H. Kim. 2013. Effects of dietary carbohydrases on growth performance, nutrient digestibility and blood characteristics in finishing pigs. J. Anim. Sci. Tech. 55:289-293.

Kornegay, E. T. and A. F. Harper. 1997. Environmental nutrition: Nutrient management strategies to reduce nutrient excretion of swine. Prof. Anim. Sci. 13:99-111.

Lay, D. C., R. L. Matteri, J. A. Carrol, T. J. Fangman, and T. J. Safranski. 2002. Preweaning survival in swine. J. Anim. Sci. 80:E74-E86.

Lee, C., L. R. Giles, W. L. Bryden, J. L. Downing, P. C. Owens, A. C. Kirby, and P. C. Wynn. 2005. Performance and endocrine responses of group housed weaner pigs exposed to the air quality of a commercial environment. Livest. Prod. Sci. 93:255-262.

Lee, J. S., E. G. Awji, S. J. Lee, D. D. Tassew, Y. B. Park, K. S. Park, M. K. Kim, B. Kim, and S. C. Park. 2012. Effect of Lactobacillus planetarium CJLP243 on the growth performance of cytokine response of weaning pigs challenged with enterotoxigenic Escherichia coli. J. Anim. Sci. 90:37093717.

Le Floc'h, N., C. Jondreville, J. J. Matte, and B. Séve. 2006. Importance of sanitary environment for growth performance and plasma nutrient homeostasis during the post-weaning period in piglets. Arch. Anim. Nutr. 60:23-34.

Le Floc'h, N., L. LeBellego, J. J. Matte, D. Melchior, and B. Séve. 2009. The effect of sanitary status degradation and dietary tryptophan content on growth rate and tryptophan metabolism in weaning pigs. J. Anim. Sci. 87:1686-1694.

LeMieux, F. M., L. L. Southern, and T. D. Bidner. 2003. Effect of mannanoligosaccharides on growth performance of weanling pigs. J. Anim. Sci. 81:2482-2487.

Li, J. and I. H. Kim. 2013. Effects of levan-type fructan supplementation on growth performance, digestibility, blood profile, fecal microbiota, and immune responses after 
lipopolysaccharide challenge in growing pigs. J. Anim. Sci. 91:5336-5343.

Li, X., J. Yin, D. Li, X. Chen, J. Zang, and X. Zhou. 2006 Dietary supplementation with zinc oxide increases IGF-1 and IGF-1 receptor gene expression in the small intestine of weanling piglets. J. Nutr. 136:1786-1791.

Liu, Y. L., D. F. Li, L. M. Gong, G. F. Yi, A. M. Gaines, and J. A. Carrol. 2003. Effects of fish oil supplementation on the performance and the immunological, adrenal, and somatotrophic responses of weaned pigs after an Escherichia coli lipopolysaccharide challenge. J. Anim. Sci. 81:2758-2765.

Marquardt, R. R., L. Z. Jin, J. W. Kim, L. Fang, A. A. Frohlich, and S. K. Baidoo. 1999. Passive protective effect of egg-yolk antibodies against enterotoxigenic Escherichia coli $\mathrm{K}^{+} 8^{+}$ infection in neonatal and early-weaned piglets. FEMS Immunol. Med. Microbiol. 23:283-288.

Mavcromichalis, I., C. M. peter, T. M. Parr, D. Ganessunker, and D. H. baker. 2000. Growth-promoting efficacy in young pigs of two sources of zinc oxide having either a high or a low bioavailability of zinc. J. Anim. Sci. 78:2896-2902.

Meng, Q. W., L. Yan, X. Ao, H. D. Jang, J. H. Cho, and I. H. Kim 2010. Effects of chito-oligosaccharide supplementation on egg production, nutrient digestibility, egg quality and blood profiles in laying hens. Asian Australas. J. Anim. Sci. 23:14761481.

Mitchell, A. D., A. M. Scholz, and H. J. Mersmann. 2001. Growth and body composition. In: Biology of the Domestic Pig (Eds. W. G. Pond and H. J. Mersmann). Cornell University Press, NY, USA. 225 p.

Mohana Devi, S., S. I. Lee, and I. H. Kim. 2015. Effect of phytogenics on growth performance, fecal score, blood profiles, fecal noxious gas emission, digestibility, and intestinal morphology of weanling pigs challenged with Escherichia coli K88. Pol. J. Vet. Sci. 18:557-564.

Moretó, M. and A. Pérez-Bosque. 2009. Dietary plasma proteins, the intestinal immune system, and the barrier functions of the intestinal mucosa. J. Anim. Sci. 87:E92-E100.

Morovat, A. and M. J. Dauncey. 1998. Effects of thyroid status on insulin-like growth factor-I, growth hormone and insulin are modified by food intake. Eur. J. Endocrinol. 138:95-103.

Munyaka, P. M., H. Echeverry, A. Yitbarek, G. Camelo-Jaimes, S. Sharif, W. Guenter, J. D. House, and J. C. RodriguezLecompte. 2012. Local and systemic innate immunity in broiler chickens supplemented with yeast-derived carbohydrates. Poult. Sci. 91: 2164-2172.

Neumann, E. J., J. B. Kliebenstein, C. D. Johnson, J. W. Mabry, E. J. Bush, A. H. Seitzinger, A. L. Green, and J. J. Zimmerman. 2005. Assessment of the economic impact of porcine reproductive and respiratory syndrome on swine production in the United States. J. Am. Vet. Med. Assoc. 227:385-392.

Nyachoti, C. M., E. Kiarie, S. K Bhandari, G. Zhang, and D. O. Krause. 2012. Weaned pig responses to Escherichia coli K88 oral challenge when receiving a lysozyme supplement. J. Anim. Sci. 90:252-260.

Ojha, S. and M. Kostrzynska. 2007. Approaches for reducing Salmonella in pork production. J. Food Prot. 70:2460-2694.

Opapeju, F. O., D. O. Krause, R. L. Payne, M. Rademacher, and C. M. Nyachoti. 2009. Effect of dietary protein level on growth performance, indicators of enteric health, and gastrointestinal microbial ecology of weaned pigs induced with postweaning colibacillosis. J. Anim. Sci. 87:2635-2643.

Owusu-Asiedu, A., S. K. Baidoo, C. M. Nyachoti, and R. R. Marquardt. 2002. Response of early-weaned pigs to spraydried porcine or animal plasma based diets supplemented with egg-yolk antibodies against enterotoxigenic Escherichia coli. J. Anim. Sci. 80:2895-2903.

Owusu-Asiedu, A., C. M. Nyachoti, S. K. Baidoo, R. R. Marquardt, and X. Yang. 2003. Response of early-weaned pigs to an enterotoxigenic Escherichia coli (K88) challenge when fed diets containing spray-dried porcine plasma or pea protein isolate plus egg yolk antibody. J. Anim. Sci. 81:1781-1789.

Pastorelli, H., J. van Milgen, P. Lovatto, and L. Montagne. 2012. Meta-analysis of feed intake and growth responses of growing pigs after a sanitary challenge. Animal 6:952-961.

Peace, R. M., J. Campbell, J. Polo, J. Creshaw, L. Russell, and A. Moeser. 2011. Spray-dried porcine plasma influences intestinal barrier function, inflammation, and diarrhea in weaned pigs. J. Nutr. 141:1312-1317.

Pluske, J. R., D. J. Hampson, and I. H. Williams. 1997. Factors influencing the structure and function of the small intestine in the weaned pig: a review. Livest. Prod. Sci. 51:215-236.

Poulsen, H. D. 1989. Zinc oxide for weaned pigs. In: Proc. 40th Annu. Mtg. Eur. Assoc. Anim. Prod., Dublin, Ireland, pp 8-10.

Poulsen, H. D. 1995. Zinc oxide for weanling piglets. Acta Agric. Scand. A. Anim. Sci. 45:159-167.

Rincker, M. J., G. M. Hill, J. E. Link, A. M. Meyer, and J. E. Rowntree. 2005. Effects of dietary zinc and iron supplementation on mineral excretion, body composition, and mineral status of nursery pigs. J. Anim. Sci. 83:2762-2774.

Roof, M. D. and D. C. Mahan. 1982. Effect of carbadox and various dietary copper levels for weanling swine. J. Anim. Sci. 55:1109-1117.

Rose-Dye, T. K., L. O. Burciaga-Robles, C. R. Krehbiel, D. L. Step, R. W. Fulton, A. W. Confer, and C. J. Richards. 2011. Rumen temperature change monitored with remote rumen temperature boluses after challenges with bovine viral diarrhea virus and Mannheimia haemolytica. J. Anim. Sci. 89:11931200.

Rostagno, M. H. and T. R. Callaway. 2012. Pre-harvest risk factors for Salmonella enterica in pork production. Food Res. Int. 45:634-640.

Sandberg, F. B., G. C. Emmans, and I. Kyriazakis. 2007. The effects of pathogen challenges on the performance of native and immune animals: The problem of prediction. Animal 1:6786.

Schutz, J. S., J. A. Carrol, L. C. Gasbarre, T. A. Shelton, S. T. Nordstrom, J. P. Hutcheson, H. Van Campen, and T. E. Engle. 2012. Effects of gastrointestinal parasites on parasite burden, rectal temperature, and antibody titer responses to vaccination and infectious bovine rhinotrachritis virus challenge. J. Anim. Sci. 90:1948-1954.

Shang, Y. 2014. Effects of Fructooligosaccharide Alone or in Combination with Phytase on Growth Performance, Nutrient Utilization, Immune Response and Gut Development of Broiler Chickens. M.Sc. thesis, University of Manitoba, Winnipeg, MB, Canada.

Shields, R. G., D. C. Mahan, and P. L. Graham. 1983. Changes in swine body composition from birth to $145 \mathrm{~kg}$. J. Anim. Sci. 
57:43-54.

Shini, S., P. Kaiser, A. Shini, and W. L. Bryden. 2008. Differential alterations in ultrastructural morphology of chicken heterophils and lymphocytes induced by corticosterone and lipopolysaccharide. Vet. Immunol. Immunopathol. 122:83-93.

Smith, J. W., M. D. Tokach, R. D. Goodband, J. L. Nelssen, and B. T. Richert. 1997. Effects of the interrelationship between zinc oxide and copper sulfate on growth performance of earlyweaned pigs. J. Anim. Sci. 75:1861-1866.

Song, M., T. M. Che, Y. Liu, J. A. Soares, B. G. Harmon, and J. E. Pettigrew. 2012. Effects of dietary spray-dried egg on growth performance and health of weaned pigs. J. Anim. Sci. 90:30803087.

Spring, P., C. Wenk, K. A. Dawson, and K. E. Newman. 2000. The effects of dietary mannanoligosaccharides on cecal parameters and the concentrations of enteric bacteria in the ceca of salmonella- challenged broiler chicks. Poult. Sci. 79:205-211.

Thacker, P. A. 2013. Alternatives to antibiotics as growth promoters for use in swine production: A review. J. Anim. Sci. Biotechnol. 4:35.

Trevisi, P., D. Melchior, M. Mazzoni, L. Casini, S. De Filippi, L. Minieri, G. Lalata-Costerbosa, and P. Bosi. 2009. A tryptophan-enriched diet improves feed intake and growth performance of susceptible weanling pigs orally challenged with Escherichia coli K88. J. Anim. Sci. 87:148-156.

Turner, J. L., S. S. Dritz, J. J. Higgins, K. L. Herkelman, and J. E. Minton. 2002. Effects of a Quillaja saponaria extract on growth performance and immune function of weanling pigs challenged with Salmonella typhimurium. J. Anim. Sci. 80:1939-1946.

Van der Peet-Schwering, C. M. C. and G. P. Binnendijk. 1995. The effect of spray-dried porcine plasma in diets with different protein sources on the performance of weanling piglets. In: Report P1. 137. Praktijkkonder-zoek Varkenshouderij, Rosmalen, The Netherland.

van Dijk, A. J., H. Everts, M. J. A. Nabuurs, R. J. C. F. Margry, and A. C. Beynen. 2001. Growth performance of weanling pigs fed spray-dried animal plasma: A review. Livest. Prod. Sci. 68:263-274.

Walk, C. L., S. Srinongkote, and P. Wilcock. 2013. Influence of a microbial phytase and zinc oxide on young pig growth performance and serum minerals. J. Anim. Sci. 91:286-291.

Wang, J. P., J. S. Yoo, H. D. Jang, J. H. Lee, J. H. Cho, and I. H. Kim. 2011. Effect of dietary fermented garlic by Weissella koreensis powder on growth performance, blood characteristic, and immune response of growing pigs challenged with Escherichia coli lipopolysaccharide. J. Anim. Sci. 89:21232131.

Wannemacher, R. W. 1977. Key role of various individual amino acids in host response to infection. Am. J. Clin. Nutr. 30:12691280 .

Webel, D. M., B. N. Finck, D. H. Baker, and R. W. Johnson. 1997. Time course of increased plasma cytokines, cortisol, and urea nitrogen in pigs following intraperitoneal injection of lipopolysaccharide. J. Anim. Sci. 75:1514-1520.

Wedekind, K. J., A. J. Lewis, M. A. Giesemann, and P. S. Miller. 1994. Bioavailability of zinc from inorganic and organic sources for pigs fed corn-soybean meal diets. J. Anim. Sci.
72:2681-2689.

Wedekind, K. J. and A. J. Lewis. 1993. Assessing zinc bioavailability with pigs fed corn-soybean meal diets. Nebraska Swine Report, Lincoln, NE, USA. 24 p.

Wellock, I. J., J. G. M. Houdijk, A. C. Miller, B. P. Gill, and I. Kyriazakis. 2009. The effect of weaner diet protein content and diet quality on the long-term performance of pigs to slaughter. J. Anim. Sci. 87:1261-1269.

White, M. E., T. G. Ramsay, J. M. Osborne, K. A. Kampman, and D. W. Leaman. 1991. Effect of weaning at different ages on serum insulin-like growth factor-I (IGF-I), IGF binding proteins, and serum in vitro mitogenic activity in swine. J. Anim. Sci. 69:134-145.

White, L. A., M. C. Newman, G. L. Cromwell, and M. D. Lindemann. 2002. Brewers dried yeast as a source of mannanoligosaccharides for weanling pigs. J. Anim. Sci. 80:2619-2628.

Whitney, M. H., G. C. Shurson, and R. C. Guedes. 2006. Effect of dietary inclusion of distillers dried grains with solubles on the ability of growing pigs to resist a Lawsonia intracellularis challenge. J. Anim. Sci. 84:1880-1889.

Xu, Z. R., X. T. Zou, C. H. Hu, M. S. Xia, X. A. Zhan, and M. Q. Wang. 2003. Effects of dietary fructooligosaccharide on digestive enzyme activities, intestinal microflora and morphology of male broilers. Poult. Sci. 82:1030-1036.

Yang, X., Y. Guo, X. He, J. Yuan, Y. Yang, and Z. Wang. 2008. Growth performance and immune responses in chickens after challenge with lipopolysaccharide and modulation by dietary different oils. Animal 2:216-223.

Yokoyama, H., R. C. Peralta, R. Diaz, S. Sendo, Y. Ikemori, and Y. Kodama. 1992. Passive protective effect of chicken egg yolk immunoglobulins against experimental enterotoxigenic Escherichia coli. Infect. Immun. 60:998-1007.

Yolken, R. H., F. Leister, S. B. Wee, R. Miskuff, and S. Vonderfecht. 1988. Antibodies to rota viruses in chickens' eggs: a potential source of antiviral immunoglobulins suitable for human consumption. Pediatrics 81:291-295.

Zannelli, M. E., K. J. Touchette, G. L. Allee, R. L. Matteri, L. A. Beausang, L. J. Luchene, and J. A. Carroll. 2000. A comparison of the immunological response to lipopolysaccharide (LPS) versus E. coli challenge in the weaned pig. J. Anim. Sci. 78:77.

Zeng, Z., S. Zhang, H. Wang, and X. Piao. 2015. Essential oil and aromatic plants as feed additives in non-ruminant nutrition: A review. J. Anim. Sci. Biotechnol. 6:7.

Zhang, B., Y. Guo, and Z. Wang. 2008. The modulating effect of $\beta-1,3 / 1,6$-glucan supplementation in the diet on performance and immunological responses of broiler chickens. Asian Australas. J. Anim. Sci. 21:237-244.

Zhao, P. Y., J. H. Jung, and I. H. Kim. 2012. Effect of mannan oligosaccharides and fructan on growth performance, nutrient digestibility, blood profile, and diarrhea score in weanling pigs. J. Anim. Sci. 90:833-839.

Zhao, P. Y., J. P. Wang, and I. H. Kim. 2013. Evaluation of dietary fructan supplementation on growth performance, nutrient digestibility, meat quality, fecal microbial flora, and fecal noxious gas emission in finishing pigs. J. Anim. Sci. 91:52805286. 